\title{
Portfolio optimization of financial commodities with energy futures
}

\author{
Lu Wang ${ }^{1}$ (D) Ferhana Ahmad ${ }^{2}$. Gong-li Luo ${ }^{1} \cdot$ Muhammad Umar ${ }^{3}$. \\ Dervis Kirikkaleli ${ }^{4}$
}

Accepted: 17 September 2021 / Published online: 24 October 2021

(c) The Author(s), under exclusive licence to Springer Science+Business Media, LLC, part of Springer Nature 2021

\begin{abstract}
The recent growth in economic and financial markets has brought the focus on energy derivatives as an alternative investment class for investors, financial analysts, and portfolio managers. The financial modeling and risk management of portfolios using the energy derivatives instrument is a requirement and challenge for researchers in the field. The energy and other commodity futures force the expert investors to investigate the broader investment spectrum and consequently diversify their portfolios using the futures instruments. Going beyond the conventional portfolios and developing out-of-the-box strategies that comply with the changing financial and economic advancements are the keys to long-term sustainability in the financial world. This study investigates the impact of diversification with five energy futures from January 2011 to July 2020 on three traditional commodity futures portfolios. The results show that diversification increased the returns while simultaneously reducing the portfolio volatility in all portfolios. The diversified portfolios provided higher returns than the traditional portfolios for the same level of risk. This study also revealed that the results might improve when a short position in the futures contracts is allowed. Moreover, we conclude
\end{abstract}

Lu Wang

wanglu0809@126.com

Ferhana Ahmad

ferhana.ahmad@1ums.edu.pk

Gong-li Luo

luogongli1112@126.com

Muhammad Umar

muhammad.umar@ucp.edu.pk

Dervis Kirikkaleli

dkirikkaleli@eul.edu.tr

1 College of Economics and Management, Shandong University of Science and Technology, Qingdao 266590, China

2 Suleman Dawood School of Business, Lahore University of Management Sciences, Lahore, Pakistan

3 UCP Business School, Faculty of Management Studies, University of Central Punjab, 1-Khayaban-e-Jinnah Road, Johar Town, Lahore, Pakistan

4 Faculty of Economic and Administrative Sciences, Department of Banking and Finance Lefke, European University of Lefke, Lefke, Cyprus 
that adding multiple energy futures in a portfolio provides enhanced diversification results, whereas the WTI crude oil futures fail to diversify any portfolio considered in the study.

Keywords Energy futures · Portfolio diversification · Commodity futures · Risk management $\cdot$ Mean-variance analysis $\cdot$ Efficient frontier

JEL Classification $\mathrm{G} 11 \cdot \mathrm{G} 1 \cdot \mathrm{G} 13 \cdot \mathrm{F} 65$

\section{Introduction}

Energy commodities have always been essential to governments and other parties in the global economic and financial worlds. These commodities are significant in countries' economic or otherwise development, and therefore countries have shown great concern about the volatile and uncertain nature of energy prices over the past decade. Due to the fluctuations and tensions around these commodity prices, especially crude oil prices, energy futures have played a crucial role in hedging and speculative trading (Su et al., 2021; Umar et al., 2021a, 2021b, 2021c). Energy commodities and futures play an essential role in diversifying portfolios as an asset class (or subclass of commodity and commodity futures) and have been known to hugely interact with financial markets (Barsky \& Kilian, 2004; Tao et al., 2020; Umar et al., 2021a, 2021b, 2021c). However, the scope of the energy futures in optimally managing and diversifying portfolios is still an under-investigated area of research. In this study, we research the diversification of commodity futures portfolios by considering three classes of commodities: agricultural, metal, and soft commodities using energy futures on WTI crude oil, natural gas, coal, heating oil, and Dow Jones electricity index.

In recent years, investors have shown great interest in diversifying their existing portfolios using commodity futures. The investors have considered commodity futures such as energy, agricultural, and metal futures as suitable alternative investments to manage and diversify their portfolios' risks. However, the research on the commodity futures and their diversification properties for managing portfolio risk is limited (You \& Daigler, 2013) even though buying and selling in futures contracts are, in principle, similar to that of stocks (Johnson, 1960; Levy, 1987). The commodity futures present opportunities for diversification of traditional portfolios due to the low correlations with other assets, high liquidity, and low transactional costs (You \& Daigler, 2013), (Gorton \& Geert Rouwenhorst, 2006) and (Chong \& Miffre, 2010). Commodity futures represent a unique class for diversification of existing portfolios, unlike physical commodities where due to high transactional, insurance, and storage costs, a direct investment could be unrealistic for portfolio diversification (Jensen et al., 2000; Su et al., 2020).

In addition to the costs, commodity futures also provide an inflation hedge that is considered advantageous in portfolio diversification using commodities. Inflation increases the commodities' prices when stocks and bonds see a downward trend (Bodie, 1983). While optimizing portfolios using commodity derivatives, You and Daigler observed that individual futures contracts worked better for portfolio diversification than futures indices. They further quoted that ex-ante portfolios dominate both naïve and traditional portfolios, and ex-post portfolios performed better than naïve portfolios using Markowitz Mean-Variance analysis and Sharpe ratio optimization techniques (You \& Daigler, 2013).

Harry Markowitz provided the basics of what we now call Modern portfolio theory in his seminal paper of 1952 (Markowitz, 1952). Markowitz considered the portfolio optimization 
problem to be based on two criteria, risk as measured by variance and return on the portfolio. Many researchers have criticized the model and have proposed improvements over the years. For instance, King extended the model for asymmetric risk measures (King, 1993), Cesarone et al. investigated the Limited Asset Markowitz model by introducing cardinality constraints (Cesarone et al., 2013) and Guerard et al. expanded the model to multi-objective portfolio optimization problem (Guerard et al., 2018). In addition to that, some authors suggested that portfolio selection is a multicriteria selection problem (Ogryczak, 2000) and some incorporated environmental and social considerations into the optimization of portfolios (Liagkouras et al., 2020). The model is still used widely in practice for active portfolio management despite the development of more sophisticated models by academicians in the years followed. Fabozzi et al. provided a survey of contributions in the theory of portfolio selection from an operations research and finance perspective. In their paper, Fabozzi et al. investigated the classical mean-variance problem, a mean-VaR model, and a mean-CVaR model and reviewed optimal estimation methods along with the robust Bayesian approach. They also recommended that more interactions between operations research and finance literature need to be conducted (Fabozzi et al., 2010).

This paper suggests diversifying the existing portfolios of commodity futures with multiple energy commodities futures. The portfolios are developed from the futures of agricultural commodities, soft commodities, and metal commodities. The selection of the commodities is based on their popularity and performance in the markets. We used the data from January 2011 to July 2020. During this period, WTI crude oil futures dropped down to a negative value of -37.63 on April 20, 2020, and the coal futures price dropped from its highest at 130.25 on January 10, 2011, to its lowest at 38.6 on May 29, 2020. The commodity futures market showed high volatility (between 21 to $132 \%$ ) and low returns (between $-52 \%$ to 9\% per annum) during the period considered for the study. During this period, COVID 19 hit the world, and we explore the diversification properties of our portfolios using energy commodities by dividing data to pre-crisis and covid 19 periods during our study.

This study contributes to the existing work in multiple ways. Firstly, the study explores and analyzes the diversification of four commodity futures portfolios by adding multiple energy futures in the existing portfolios on a recent dataset. In the previous studies that have been conducted on the diversification either only used crude oil futures for the purpose (Geman \& Kharoubi, 2008; Kang et al., 2017; Sarwar et al., 2019a, b; Elsayed et al., 2020), or studied the effects of crude oil and other energy futures on equities or equities index (Galvani \& Plourde, 2010; Bessler \& Wolff, 2015; Rehman et al., 2019). The few studies that have analyzed some commodities with energy commodity futures have been conducted on either an older data (You \& Daigler, 2013; Kang et al., 2017) or the focus of the study was to study long and short term asymmetries of energy and non-energy futures (Rehman et al., 2019). However, the previous few years have been crucial for energy futures, especially for crude oil and coal futures, requiring further exploration of the futures' diversification properties. We, therefore, think that in the current market dynamics, exploration of diversification of commodities' futures using energy futures is required on a recent data set.

Secondly, the study provides risk-return profiles of existing portfolios with and without the addition of energy futures and plots a comparison of the efficient frontier for Markowitz's mean-variance analysis. Interestingly, such an analysis has not been carried out in a study on diversification through energy commodities futures portfolios. In addition to that, we analyze portfolios by adding multiple energy futures to the existing commodity portfolios. Therefore, this study makes it the first of its kind in this regard. In addition to that, we have used multiple metrics for the optimization of portfolios. The metrics included naïve portfolios, the mean-variance optimization portfolios for various risk levels, and the optimized Sharpe ratio. 
The analysis revealed that the portfolio diversification using energy futures provided better returns for the same level of risk than the commodities portfolios without energy futures.

Additionally, more impressive results were observed in terms of the risks of the diversified portfolios. It was noted that the inclusion of energy futures significantly reduced the risk of the portfolios while simultaneously increasing the returns expected from the diversified portfolios. The overall effect was also captured in an increased optimized Sharpe ratio. We also analyzed that when short positions in the futures are allowed, diversification can be increased significantly.

Thirdly, we investigated the portfolios' diversification using WTI crude oil futures only and observed that the crude oil futures do not diversify the portfolios for the period chosen for our study. Multiple studies have been conducted in the literature on diversification of the equity portfolios using crude oil and its futures (Geman \& Kharoubi, 2008; Galvani \& Plourde, 2010; Liu \& Tu, 2012; Umar et al., 2021a, b, c; Sarwar et al., 2019a, b). Our study encourages financial analysts and fund managers to explore energy futures other than crude oil futures for their investment and diversification purposes.

Fourth, we break the data set into two periods around the covid 19 crisis: the pre-crisis period from January 2011 to March 11, 2020, and the covid 19 periods from March 11, 2020. March 11, 2020, is chosen as the divider between the data because the World Health Organization (WHO) declared covid 19 a pandemic on this date. We analyze the portfolio properties for both periods using the metrics mentioned above: naïve portfolio, mean-variance optimization, and the optimized Sharpe ratio. Our results hold for both pre-crisis and covid 19 periods, and the diversification through energy derivatives is significant.

Lastly, in addition to the above-mentioned metrics for portfolio optimization, we check the diversification properties of energy commodities derivatives by restricting the weights of each asset in the portfolio to lie between 5 and 50\% while maximizing the Sharpe ratio. We found that our results hold for almost all the commodity classes discussed in the study. We further check the robustness by using Young's minimax strategy for portfolio diversification using energy commodities futures. The results are pretty conclusive and encourage fund managers and financial analysts to study energy futures for diversifying their existing commodities portfolios.

The rest of the study is organized in the following way. A detailed literature review is provided in Sect. 2. Section 3 provides an overview of the data and methodologies used in our study. Section 4 details the study results for the different portfolios and metrics used in the study, their diversification through energy futures, and a comparison of the results. We also divide the data into pre-crisis and covid 19 periods and study the portfolio diversification characteristics for energy commodities futures in the section and additional constraints and minimax strategy results. Discussion on the results in the light of previous studies and policy implications is provided in Sect. 5. We conclude the paper by summarizing results and future directions for research in Sect. 6.

\section{Literature review}

Globalization and economic developments in the countries have brought energy commodities and derivatives to the front lines, especially in first-world economies. Not only that, the energy commodities are essential for economic growth, but these also provide investment and diversification opportunities for portfolios to the investors and portfolio managers. With the developments in the futures markets and the derivatives being accepted as an alternative 
investment class, the low transactional, storage, and insurance costs, investors are compelled to explore the diversification and development of portfolios using commodity and especially energy futures. The change is rapid but natural in recent years, given the direction of the growth in the world economies. Therefore, portfolio managers are destined to change their trading strategies by exploring new avenues of diversification using energy futures.

The commodity futures returns have historically shown low correlations with the financial assets and usually moved in opposite directions to traditional portfolios, especially during macroeconomic shocks and therefore pushed the investors to devise optimized asset allocation and portfolio strategies to hedge and diversify risk using commodity futures (Kang et al., 2017). Kang et al. applied a multivariate DECO-GARCH model and spillover index to examine the spillover effects among gold, silver, WTI crude oil, corn, wheat, and rice futures market. They concluded that a positive equicorrelation between commodity futures market returns exists that is increased sharply during the financial crisis of 2007 by using data from January 2002 to July 2016. They further suggested that the benefits of diversification using international portfolios are reduced during a financial and economic crisis. They also found a strong spillover impact during the financial crisis by identifying bidirectional return and volatility spillovers across commodity futures markets.

Liu and Tu investigated jump spillover effects on five petroleum futures for European markets and concluded that the jump spillover exists in the market, and historical sample correlations are not a good measure to find the jump spillovers (Liu \& Tu, 2012). Using the Bayesian MCMC approach, they estimated a jump-diffusion process for each of the futures on a data set from November 2006 to October 2008. They also concluded that the benefits from diversification in energy markets are reduced during the tranquil period due to the jump spillover.

While studying the effects of volatility spillovers in oil and stock markets for different economies, (Sarwar et al., 2020) observed bidirectional spillover in the Karachi stock market, unidirectional spillover in the Shanghai stock market and mixed behavior in the Bombay stock market. In addition to that, the authors found that there was no significant difference between the results before the 2008 financial crisis and the results after the financial crisis. (Sarwar et al., 2019a, 2019b) also investigated volatility spillover and hedging in Asian oil-importing countries. Their results showed that China has no evidence of volatility spillover, Nikkei stock returns show a bidirectional volatility spillover, and Indian stock returns show unidirectional volatility spillover between stock returns and oil returns. They further suggested that oil assets were helpful in reducing the risk of a portfolio; however, the investors should choose more stock than oil assets to form an optimal portfolio.

In a study on volatility spillover between the stock markets of oil exporting and importing countries and the oil market and its implications on portfolio management (Khalfaoui et al., 2019) found less evidence between the interdependence of stock markets for oil-importing and exporting countries. They further reported that investors should hold more oil assets in the portfolio to hedge their risk in oil-exporting countries. Another article by (Sarwar et al., 2018) investigated the effects of energy variables such as oil, electricity prices, and electricity consumption on the firms' return of 397 Pakistani firms, industry return of 12 listed industries, KSE 100 index, and gross domestic product of Pakistan. They found that oil has a significantly positive effect on industry return, index return, and economic growth, whereas electricity prices have a significant negative impact on firms' stock returns, industry return, index return, and economic growth as measured by gross domestic product.

In a recent study by Elsayed et al., time-varying volatility spillover effects are being studied between conventional and non-conventional energy markets and global financial markets using indices as proxies of the markets on data from December 2000 to December 
2018. They observed high interdependence in the volatilities of oil and financial markets and that the impact of energy markets becomes significant in the global financial market when broken into pre, mid, and post-financial crisis. The optimal diversification strategies show that the hedge ratios are volatile, and a higher weightage is given to stocks than to oil (Elsayed et al., 2020).

Some studies showed that diversification through commodity futures might increase the risk-adjusted return. While working on data from 1950 to 1976, Bodie and Rosansky observed that the risk of a diversified portfolio through commodity futures with a weightage of 60-40 in all stock and commodity portfolio, respectively, reduced one-third of the portfolio risk while keeping the return unchanged (Bodie \& Rosansky, 1980). Jensen et al. also observed that Markowitz optimization, when conducted on a data set from 1973 to 1997, for a range of risk levels gave high weightage to commodity futures and increased returns of resulted portfolios (Jensen et al., 2000). While commenting on the dearth of literature on the diversification benefits of commodity futures, Cheung et al. showed that the alleged benefits of diversification using commodity futures exist though may not be as convincing as the previous studies show. They argued that the long-term benefits are due to the infrequent upswings in the commodity markets and may not be universal to every country's market (Cheung et al., 2010).

Stock portfolios, when diversified using commodities, provide better diversification properties than a similar portfolio without commodities. Stocks and Commodity futures are negatively correlated, and therefore adding commodities provide better risk and return tradeoffs and a better efficient frontier (Gorton \& Geert Rouwenhorst, 2006). The regulatory changes and financial developments, trading in commodity markets have made it easy for investors and portfolio managers to participate in the commodity market. (Sadorsky, 2014) studied volatility dynamics between emerging markets and commodities on a data set from January 3, 2000, to June 29, 2012, of MSCI emerging market index, oil, wheat, and copper. The author concluded that optimal weights and hedge ratios need frequent updating owing to their variable nature and that diversification benefits reduced after the 2008 crisis due to increased conditional correlations between emerging markets, oil, copper, and wheat. (Chang et al., 2011) also investigated the performance of several multivariate volatility models for WTI and Brent crude oil to calculate optimal weights and hedge ratios on data from November 1997 to November 2009. Their results show that optimal portfolio weights for Brent crude oil give a higher proportion to crude oil futures in multivariate volatility models. The results in WTI crude futures were found to be mixed depending on different measures.

While studying the additional value commodities add to the traditional multi-asset portfolios, Bessler and Wolff concluded that aggregated commodity index, precious and industrial metals, and energy commodities improve the performance of a stock and bond portfolio (Bessler \& Wolff, 2015). They used indices as proxies for an out-of-sample analysis on monthly data from January 1986 to December 2013. They also remarked that previous in sample portfolio gains tend to overstate actual gains from commodity investments. (Gatfaoui, 2016) studied the behavior of the US Stock market for possible interactions between the US market and US Natural gas and crude oil markets. She highlighted that the three markets have time-dependent structural changes while studying the data on returns for the three markets from January 1997 to January 2013 and concludes that it is difficult to forecast future prices and dependency due to the unstable dependency. She further extended the study (Gatfaoui, 2019) by implementing portfolio optimization for different variance regimes by minimizing risk metrics. She argued that such a regime dependency analysis was required for an active portfolio management strategy given the dependence structure of the three markets (US Stocks, Oil, and Gas). 
Some researchers have worked on the diversification of equity portfolios using crude oil futures. Geman and Kharoubi (Geman \& Kharoubi, 2008) used copula functions to capture the nonnormality of returns in both equity stocks and oil futures. They further concluded that the futures contract's longer maturity provides better diversification as the negative correlation results are more pronounced. (Galvani \& Plourde, 2010) studied the diversification of energy stocks using energy futures on daily data of five energy derivatives and 15 equities from January 1990 to February 2008. They concluded that futures for natural gas, unleaded gasoline, and crude oil diversify the stock portfolio of a passive investor by overall reducing the level of risk. However, they also suggested that energy futures' inclusion does not provide any additional reward for risk-taking in maximizing compensation portfolio.

Rehman et al. investigate long- and short-term behavior of energy and non-energy futures on a weekly dataset from January 2010 to December 2018. They observed that the crude oil future has a negative effect on gold and silver prices in the long run and therefore provides better diversification results when combined with these two metals (Rehman et al., 2019). Whereas gas futures provide more diversification for copper, wheat, platinum, and palladium, coal futures provide diversification opportunities when combined with gold, silver, and wheat. In another attempt to study portfolio diversification and energy futures, Wen and Nguyen studied the effects of commodity futures diversification on Chinese energy stocks. They applied copula function along with multiple risk-based measures to show that the commodity futures do not improve risk-adjusted returns for energy stock portfolios on data from November 2010 to January 2015 on Chinese energy stocks and four metal and agricultural futures (Wen \& Nguyen, 2017). However, the commodity futures reduce the diversified portfolios' volatilities, especially during the extensive market downturn periods.

Hernandez investigated the Australian market for the riskiness behavior of oil, gas, coal, and uranium on a data set from January 2005 to July 2012 (Arreola Hernandez, 2014). He concluded that oil stocks have higher dependence risks compared to other stocks and that the fund managers should avoid investing in oil in their portfolios and should hold gas, coal, and uranium, especially during the financial crisis. (Sarwar et al., 2019a, b) studied the portfolio optimization and importance of oil assets from a Pakistani market investor perspective. They used the BEKK-GARCH model on daily data of 107 Pakistani firms and WTI crude oil from January 6, 2000, to August 18, 2017. They found strong evidence of volatility spillover in the Pakistani firms' stocks and WTI crude oil and showed interdependence between them. They also concluded that manufacturing firms could diversify their risk by optimally giving more than $50 \%$ weight to oil assets than the firms' stocks. They further showed that a more significant portion of investment should be in the firms' stocks to form an optimal portfolio in case of oil and gas firms rather than in the oil assets. A summary of the previous literature on diversification using energy futures is provided in Table 1.

In a recent study on the risk management of energy instruments using cryptocurrencies, Huynh et al. studied the role of cryptocurrencies in the financial modeling and risk management of energy instruments especially crude oil by using data from April 2013 to April 2019 using entropy transfer analysis to examine information spillover. They concluded that the US crude oil market is a receiver of information flows from cryptocurrencies whereas the European crude oil market is a sender. They also found that over half of the cryptocurrencies, considered in their study, were interconnected with the crude oil market and therefore their results have important implications for the investors and policy makers (Huynh et al., 2020).

It is been observed that the literature on the diversification of multiple commodity futures portfolios using multiple energy futures is scarce. Previous studies have either worked on diversification using crude oil futures only (Geman \& Kharoubi, 2008; Kang et al., 2017; Sarwar et al., 2019a, b; Elsayed et al., 2020), or studied the effects of crude oil and other 
Table 1 Summary of the literature review on diversification of portfolios with energy futures comprising of authors, variables of the studies, data and results

\begin{tabular}{|c|c|c|c|}
\hline References & Variables & Data & Results \\
\hline $\begin{array}{l}\text { Geman and } \\
\text { Kharoubi } \\
(2008)\end{array}$ & $\begin{array}{l}\text { S\&P 500, WTI Crude oil } \\
\text { futures }\end{array}$ & $\begin{array}{l}\text { May 2, } \\
1990 \text {-September 1, } \\
2006\end{array}$ & $\begin{array}{l}\text { The maturity effect of WTI crude } \\
\text { oil futures has been studied on } \\
\text { the S\&P } 500 \text { as a proxy of } \\
\text { stocks. It has been concluded } \\
\text { that the distant maturity futures } \\
\text { lead to an excellent } \\
\text { diversification for both an } \\
\text { upward and downward trending } \\
\text { equity market }\end{array}$ \\
\hline $\begin{array}{l}\text { Galvani and } \\
\text { Plourde } \\
(2010)\end{array}$ & $\begin{array}{l}\text { Futures on light sweet } \\
\text { crude oil WTI, unleaded } \\
\text { gasoline, natural gas, } \\
\text { Brent crude oil, and } 15 \\
\text { equities (US oil and } \\
\text { gas-related companies) }\end{array}$ & $\begin{array}{l}\text { January } 1990- \\
\text { February } 2008\end{array}$ & $\begin{array}{l}\text { Futures on energy commodities } \\
\text { fail to enhance the return or risk } \\
\text { for investors who hold similar } \\
\text { stocks in buy and hold } \\
\text { strategies. However, the energy } \\
\text { futures allow passive investors } \\
\text { to reduce the risk in their } \\
\text { positions on energy stocks }\end{array}$ \\
\hline $\begin{array}{l}\text { Liu and Tu } \\
\text { (2012) }\end{array}$ & $\begin{array}{l}\text { Brent crude oil futures, } \\
\text { natural gas futures, } \\
\text { heating oil futures, } \\
\text { gasoline futures, and } \\
\text { fuel oil future } \\
\text { (European market) }\end{array}$ & $\begin{array}{l}\text { September } 29 \text {, } \\
2006-O c t o b e r ~ 29, \\
2008\end{array}$ & $\begin{array}{l}\text { The authors found strong } \\
\text { evidence for the existence of } \\
\text { jump spillover in the crude oil } \\
\text { and natural gas futures. They } \\
\text { further examine whether the } \\
\text { jump spillover affects portfolio } \\
\text { diversification in energy } \\
\text { commodities and found that the } \\
\text { diversification benefits can be } \\
\text { reduced for the tranquil period } \\
\text { when jump spillover is present } \\
\text { but may not affect the crisis } \\
\text { period }\end{array}$ \\
\hline $\begin{array}{l}\text { You and } \\
\text { Daigler } \\
(2013)\end{array}$ & $\begin{array}{l}\text { Weekly data on two } \\
\text { commodity index, } 5 \\
\text { stock index, } 6 \text { interest } \\
\text { rates contracts, } 7 \\
\text { currencies, } 21 \\
\text { commodity futures }\end{array}$ & 1994-2010 & $\begin{array}{l}\text { The mean-variance optimization } \\
\text { techniques provide better results } \\
\text { than using indexes that are } \\
\text { naively weightage for portfolio } \\
\text { managers. Ex-post portfolios } \\
\text { provide better results than } \\
\text { naively weighted portfolios and } \\
\text { suggest further exploration }\end{array}$ \\
\hline $\begin{array}{l}\text { Bessler and } \\
\text { Wolff } \\
(2015)\end{array}$ & $\begin{array}{l}\text { S\&P 500, Barclays US } \\
\text { aggregate govt bond } \\
\text { index, S\&P GSCI index, } \\
\text { S\&P GSCI light energy } \\
\text { index, } \\
\text { self-constructed-equally } \\
\text { weighted commodity } \\
\text { index excluding } \\
\text { agriculture and livestock }\end{array}$ & $\begin{array}{l}\text { January } \\
\text { 1986-December } \\
2013\end{array}$ & $\begin{array}{l}\text { Out of sample benefits of } \\
\text { commodities are much lower } \\
\text { than previously stated. Most } \\
\text { asset allocation strategies } \\
\text { preferred aggregate commodity } \\
\text { index and industrial metals for } \\
\text { performance enhancement } \\
\text { followed by energy }\end{array}$ \\
\hline
\end{tabular}


Table 1 (continued)

\begin{tabular}{|c|c|c|c|}
\hline References & Variables & Data & Results \\
\hline $\begin{array}{l}\text { Kang et al. } \\
\text { (2017) }\end{array}$ & $\begin{array}{l}\text { Gold, Silver, WTI Crude } \\
\text { oil, corn, wheat, and rice }\end{array}$ & $\begin{array}{l}\text { January 4, 2002, to } \\
\text { July } 28,2016\end{array}$ & $\begin{array}{l}\text { Positive equicorrelation level } \\
\text { jumps during financial and } \\
\text { economic turmoil, return and } \\
\text { volatility spillover indexes have } \\
\text { a bidirectional behavior across } \\
\text { commodity markets, and gold } \\
\text { and silver are net information } \\
\text { transmitter to the other four } \\
\text { commodity futures }\end{array}$ \\
\hline $\begin{array}{l}\text { Gatfaoui } \\
(2019)\end{array}$ & $\begin{array}{l}\text { US Natural gas, crude oil, } \\
\text { S\&P 500, S\&P1500, } \\
\text { S\&P Midcap 400, S\&P } \\
\text { SmallCap } 600\end{array}$ & $\begin{array}{l}\text { January 8, } \\
\text { 1997-October 30, } \\
2017\end{array}$ & $\begin{array}{l}\text { Regime specific dependence } \\
\text { structure for portfolio } \\
\text { optimization is being studied. } \\
\text { The authors concluded that } \\
\text { diversification through power } \\
\text { commodities is a function of risk } \\
\text { measures used and dependence } \\
\text { structure between the three (gas, } \\
\text { oil, and S\&P indices) }\end{array}$ \\
\hline
\end{tabular}

Rehman

et al.

(2019)

Crude oil, gas, coal, gold, silver, copper, platinum, palladium, and wheat (weekly)

Sarwar et al. (2019a, b)

107 Pakistani listed firms, WTI Crude oil

January

2010-December

2018

January 6 ,

2000-August 18, 2017

\footnotetext{
Elsayed et al. CEPI, MSCI WEPI, (2020)
}

December 28,

2000-December 31, 2018
Short- and long-term asymmetric relationship between energy and non-energy futures is investigated. Crude oil offers more diversification benefits when combined with gold or silver. Gas futures provide more diversification benefits when combined with copper, wheat, platinum, and palladium. Coal provides better diversification with gold, silver, or wheat

The authors suggested a strong dependence between WTI crude oil and Pakistani firms and suggests that it was hard to deny volatility spillover in the markets. The manufacturing sector is adversely affected by oil market volatility. It is also empirically shown that for an optimal portfolio in manufacturing firms, more than half of the investments are required in oil assets. However, in oil and gas firms, a significant portion of the optimal portfolio is given to the firms' stocks

The study concludes that the contribution of oil market volatility to global financial markets is insignificant, and oil shocks are exogenous. Hedge ratios are volatile, with the highest volatility being observed during the financial crisis. The optimal portfolio is heavily weighted towards stocks 
energy futures on equities or equities index (Galvani \& Plourde, 2010; Bessler \& Wolff, 2015; Rehman et al., 2019). Couple of studies have analyzed some commodities with energy commodity futures. The studies were either conducted on an older data set (You \& Daigler, 2013; Kang et al., 2017) or the focus of the study was to study long and short term asymmetries of energy and non-energy futures (Rehman et al., 2019). The last few years have been crucial for energy futures, especially for crude oil and coal futures, requiring further exploration of the futures' diversification properties. We, therefore, target the limitation in literature by exploring and analyzing the diversification of multiple commodity futures portfolios by adding multiple energy futures (Crude oil, Heating oil, Coal, Natural gas, Dow Jones Electricity index) in the existing portfolios on a recent dataset. Therefore, we work on a recent data set and explore the market dynamics for diversification of commodities' futures using energy commodity futures.

Additionally, while analyzing portfolios' diversification using WTI crude oil futures, we observed that for the period chosen for our study, the crude oil futures do not provide any diversification to the chosen portfolios. Multiple studies have been conducted in the literature on diversification of the equity portfolios using crude oil and its futures (Geman \& Kharoubi, 2008; Galvani \& Plourde, 2010; Liu \& Tu, 2012; Sarwar et al., 2019a, b). For the chosen time period, however, we find that crude oil futures do not provide diversification whereas multiple energy futures provide significant diversification in terms of reduced risk and increased return on the portfolios. Therefore, our study encourages financial analysts, fund managers and investors to explore energy futures other than the famous crude oil futures for the investment and diversification purposes.

The study also improves on the existing literature by investigating the risk-return profiles of existing portfolios with and without the addition of energy futures and plotting a comparison of the efficient frontier for Markowitz's mean-variance analysis. Interestingly, the current literature does not provide any such analysis on diversification through energy futures for commodity portfolios. Therefore, this study makes it the first of its kind in this regard. In addition to that, we have used multiple metrics for the optimization of portfolios. The metrics included naïve portfolios, the mean-variance optimization portfolios for various risk levels, and the optimized Sharpe ratio. Further to that, we break the data into pre-covid 19 and covid 19 to explore the diversification properties of energy commodities futures on existing commodities portfolios under the on-going situation. Additionally, we check our results of restricted constraint and minimax strategy of Young for robustness. We also analyze the short positions in the underlying futures contracts and the impact on diversification.

\section{Data and methodology}

This section details the data and methodology for the analysis conducted in the study. The study is conducted to investigate the characteristics of energy commodity futures on optimizing and diversifying different financial commodities portfolios. The study analyzes three portfolios of financial commodities on different optimization metrics with and without diversification using energy commodities futures derivatives. The study investigates naïve portfolios with and without energy commodity futures derivatives for agricultural commodities' futures portfolios, soft commodities futures portfolios, and metals commodities' portfolios. The study also investigates the portfolio diversification using optimized Sharpe ratios for all the portfolios with and without energy futures. In addition to that, the study 
provides the Markowitz Mean-Variance portfolio analysis that maximizes the expected portfolio return for a given risk as measured by standard deviation and plots the efficient frontier for all the commodity portfolios with and without energy futures.

\subsection{Data}

The study explores the effects the energy futures have on the diversification of other commodities' portfolios. The study uses four different types of commodities: Agricultural commodities including Rice, Canola, Wheat, Soyabean and Corn; Soft commodities including Sugar, Cotton, Cocoa, and Orange juice; Metals including Copper, Uranium, Iron, Gold, and Silver; and Energy commodities including Dow Jones Conventional Electricity index, Heating Oil, Coal, Natural Gas, and Crude oil. The list of commodities is provided in Table 2. The data on the futures prices of commodities is downloaded from investing.com. The data used in the study is from January 4, 2011, to July 31, 2020 and is collected on daily basis. The data accounts for 2332 entries for each commodity future, totals 11,660 entries for the energy futures, and 44,308 in total for all commodities. The data is comprehensive for the study and spans almost a decade. In addition to the data on commodities' futures, the risk-free rates used in the study are the 1-year US Treasury note rates, recorded on July 31, 2020.

Table 3 provides descriptive statistics of the commodities' futures used in the study. It is worth noting that over the previous decade, all the commodities futures provided negative returns except Gold and Dow Jones Conventional Electricity Index, which provided annualized positive returns.

The descriptive statistics for Crude oil are quite exciting and noteworthy. Crude oil futures showed the highest volatility of $132 \%$, with a maximum daily return of $31.96 \%$ and a minimum daily return of $-305.97 \%$ during the decade the study is being conducted. In addition to that, crude oil has shown a very high value, 1638, of kurtosis and skewness of -37.03 , making it the most volatile commodity futures amongst all in the study. During the decade, gold had the lowest volatility of $19.93 \%$ due to its stable nature. It is observed that Cocoa futures have the lowest kurtosis of 1.13 during the decade. Rice, Corn, Uranium, and coal also show a high kurtosis in the range of 35-50. A mixed behavior is observed for commodity future skewness crude oil futures showing the highest negative skewness $(-37.03)$, Orange juice and coal showing small positive correlation, and gold and cocoa showing smaller negative skewness.

Table 2 Commodity futures used in the study

\begin{tabular}{llll}
\hline Agricultural commodities & Soft commodities & Metals & Energy \\
\hline Rice & Sugar & Copper & Dow Jones Electricity index \\
Canola & Cotton & Uranium & Heating Oil \\
Wheat & Cocoa & Iron & Coal \\
Soybean & Orange Juice & Gold & Natural Gas \\
Corn & & Silver & Crude Oil \\
\hline
\end{tabular}




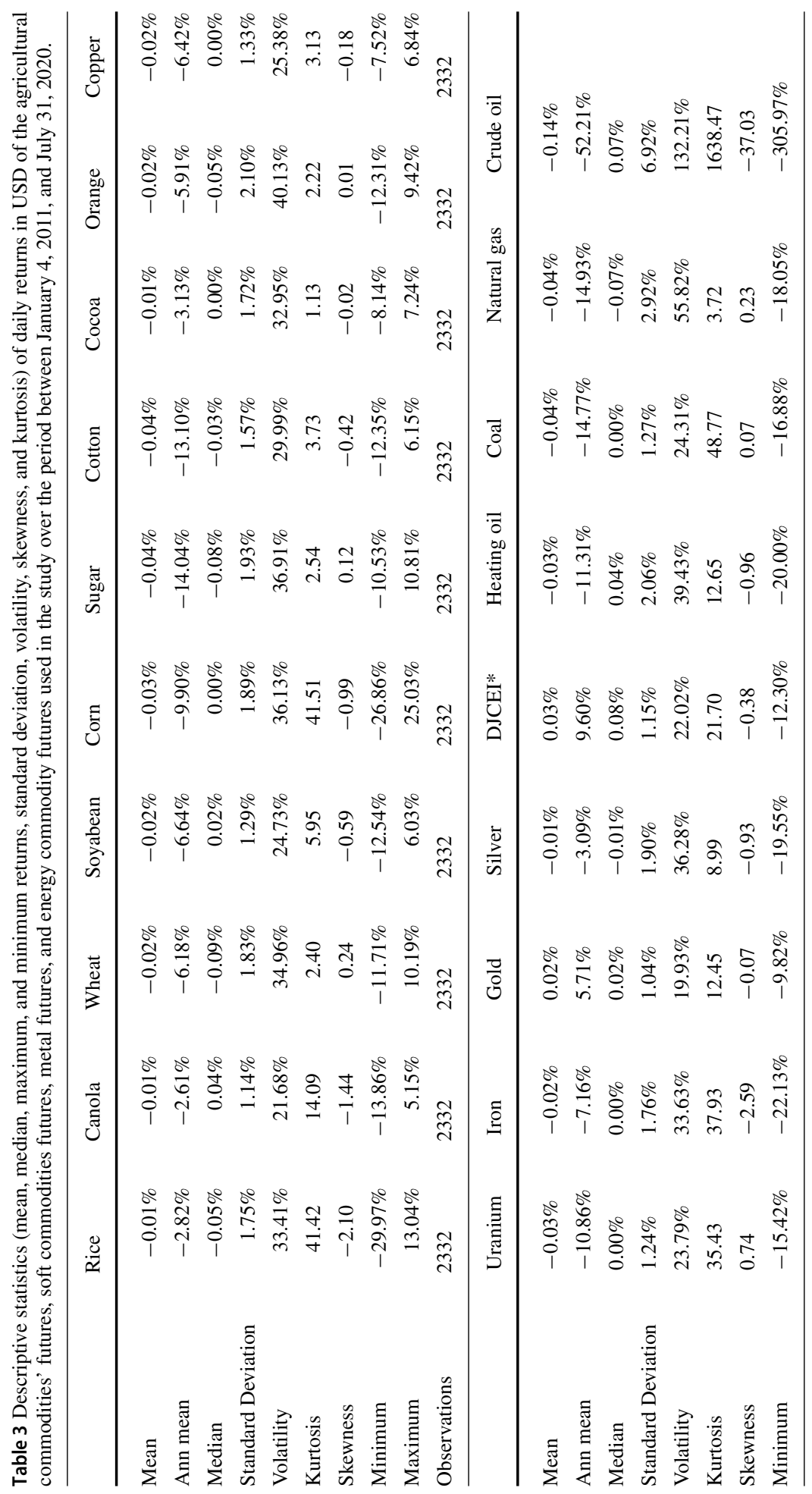




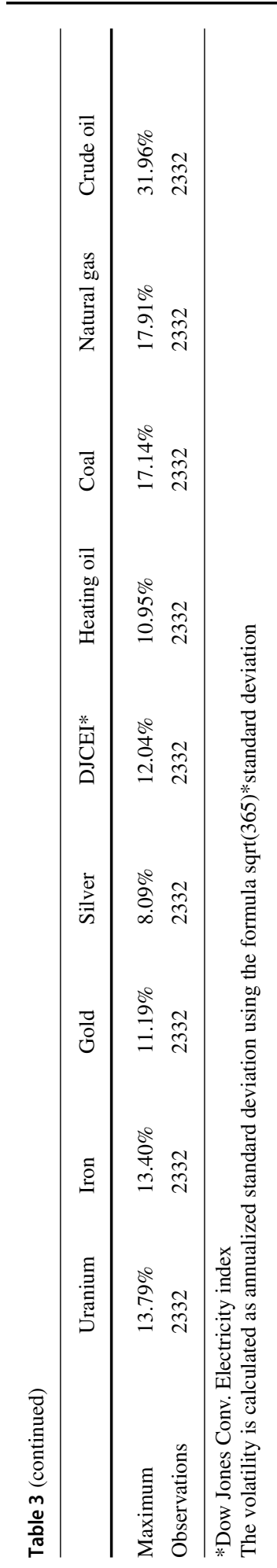




\subsection{Optimization techniques}

The following section and subsections provide optimization techniques used in the study. The data on commodities futures is being collected daily. We, therefore, calculate the log-returns on the data daily using the formula,

$$
R_{t, i}=\log \left[\frac{F_{t, i}}{F_{t-1, i}}\right],
$$

where $F_{t, i}$ is the futures price of $i$ th commodity on day $t . F_{i, t-1}$ is the futures price of the same commodity on the previous day. $R_{t, i}$ is the return on commodity $I$ on day $t$. We further calculate.

the expected return and standard deviation for each commodity futures using the following formulae:

$$
\begin{array}{r}
\mu_{i}=\mathbf{E}\left(R_{i}\right)=\frac{\sum_{t=1}^{n} R_{t, i}}{n}, \\
\sigma_{i}=\sqrt{\frac{\sum_{t=1}^{n}\left(R_{t, i}-\mu_{i}\right)^{2}}{n-1}},
\end{array}
$$

where $n$ is the number of observations for $i^{t h}$ commodity. In our study, $i$ is $1, \ldots, 19$, and $n$ is 2332 for each commodity. The above formulae provide daily returns and standard deviations for each commodity. We then annualize the values for both return and standard deviation for each commodity futures. Portfolios' returns and variances are calculated for the analysis using the returns and variances of the individual commodities' futures. The portfolios' return and variance are used in calculating returns and variance of naïve portfolios, optimized portfolios using Markowitz Mean-Variance analysis, and optimized Sharpe ratios.

\subsection{Markowitz Mean-Variance optimization (Markowitz, 1952)}

The modern portfolio theory was established by Harry Markowitz in 1952 that won him a Nobel prize later on. Markowitz developed the theoretical contributions of Markowitz Mean-Variance analysis that played a crucial role in corporate and global financial economics. The conceptual framework provided the optimal weights of assets in an investment portfolio by maximizing return for a given level of risk in the portfolio. In addition to that, the framework worked perfectly well for a dual problem where optimal weights can be found by minimizing the level of risk for a given expected portfolio return.

The portfolio returns can by calculated using returns on individual commodities that formulate the portfolio according to the following formula. For a portfolio of $m$ commodities, the return on a portfolio, $\mathbf{E}(R)$, is defined as

$$
\mathbf{E}(R)=w^{T} \mu,
$$

where $\mu=\left(\mu_{1}, \mu_{2}, \ldots, \mu_{m}\right)$ is the vector of returns on the commodity futures that formulate the portfolio and $w=\left(w_{1}, w_{2}, \ldots, w_{m}\right)$ is the vector of weights of the commodities futures in the portfolio. The variance of the portfolio is calculated as,

$$
\text { Variance }=w^{T} \Sigma w,
$$

where $\Sigma$ denotes the variance-covariance matrix of the commodities in the portfolio. Therefore, the following problem is solved in the study to optimize the expected portfolio return 
for a given level of risk as calculated by portfolio variance:

$$
\begin{aligned}
& \operatorname{Max} \mathbf{E}(R) \\
& \text { subject to } w^{T} \Sigma w=c, \\
& \sum_{i=1}^{m} w_{i}=1, \\
& w_{i} \geq 0, \quad \text { for all } i
\end{aligned}
$$

where $c$ is the given level of risk, as measured by the variance.

The problem is solved by constraining the weights in the portfolio. The third condition suggests that the weight of all the commodity futures is non-zero. By putting this condition in the problem formulation, it is forced that only long sales are allowed. The second condition suggests that all the investments must be made in the commodities that formulate the portfolios. That is, the sum of all the weights should be 1 . The expected portfolio return is maximized by giving different levels of risk in the portfolio. The results are then used to plot an efficient portfolio of the commodities portfolios with and without energy futures.

We also optimize the Sharpe ratio to observe the effects of diversification on the commodities' futures portfolios by including the energy futures in the portfolios.

\subsection{Sharpe ratio}

In addition to the naïve and Markowitz Mean-Variance optimization, we optimize the Sharpe ratio to find optimal weights of commodities' futures in the portfolios. The Sharpe ratio measures excessive return from the portfolio over the risk-free return rate per unit of risk taken. The formula for finding the Sharpe ratio is

$$
\text { Sharpe ratio }=\frac{\mathbf{E}(R)-r_{f}}{\text { Standard deviation }},
$$

where $r_{f}$ is the annualized risk-free rate of return, $\mathbf{E}(R)$ is the expected annual return from the portfolio and the standard deviation is the square root of the annualized variance.

The ratio was developed by William Sharpe in 1966 as a measure of risk-adjusted return (Sharpe, 1966). The formula can be used to compute Sharpe ratios for individual investments and to compare different investments. A higher Sharpe ratio indicates that the portfolio provides more excessive return on risk-free rate per unit of risk taken and hence takes into account the risk factor in the investment portfolio.

We also solve the optimization problem by using the Sharpe ratio. The problem becomes

$$
\operatorname{Maximize} \frac{w^{T} \mu-r_{f}}{\sqrt{w^{T} \Sigma w}},
$$

Subject to

$$
\sum_{i=1}^{m} w_{i}=1 \text {, }
$$

where $w=\left(w_{1}, w_{2}, \ldots, w_{m}\right)$ are the weights of the commodities in the portfolio. The condition, $\sum_{i=1}^{m} w_{i}=1$, force the sum of weights of commodities in the portfolio to be equal to 1. We solve the maximization problem by first allowing for long positions in the commodities' futures by enforcing another condition $w_{i} \geq 0 \forall i$ that is the weight in each commodity 
future is non-negative. We further solve the optimization problem by allowing short sales in the commodities to study the diversification in the portfolios using energy futures. Such optimization is achieved by removing the condition of non-negativity on the weights, that is, we allow $w_{i}$ to take on any value on the real line. The problem is solved using the solver routine in Excel for each portfolio in the study.

The research study explores the diversification results of energy futures on portfolios of financial commodity futures. The research considers four portfolios: Agricultural commodities futures, Soft commodities futures, Metal futures, and all of the previously mentioned commodities futures. The following section provides results on the diversification of the naïve portfolio, efficient frontiers of the portfolios, and optimized Sharpe ratio results for portfolios with and without diversification through energy commodities futures.

\section{Results}

The section presents the results for different commodity portfolios along with the diversification of the portfolios using energy futures contracts. Energy futures and derivatives have gained tremendous interest from investors and researchers in the past decade. From the portfolio managers' perspective, investing in commodity futures as an alternative investment is to improve and diversify a portfolio. The diversification properties of energy futures in financial commodity futures are unexplored, and we provide the results of this new question in this section. In addition to that, we break the data into the pre-covid and covid 19 periods for in-depth analysis of results. We also check results against additional constraints on the weight of the assets in the optimized portfolio.

\subsection{Results for commodity futures with long positions in assets}

The energy futures portfolio consists of crude oil, heating oil, coal, natural gas, and Dow Jones electricity index futures. We have seen in Table 3 that the market of energy futures has been volatile, with crude oil being the most volatile futures of the chosen set. Figure 1 provides the risk and returns profile of the energy futures portfolio. The problem of maximizing return subject to a given risk measured by standard deviation is solved as Markowitz Mean-Variance analysis is conducted for different risk levels. The return of the portfolio reasonably good for the risk level around $20 \%$ per annum. Table 4 provides naïve and optimized Sharpe

\section{Energy futures portfolio}
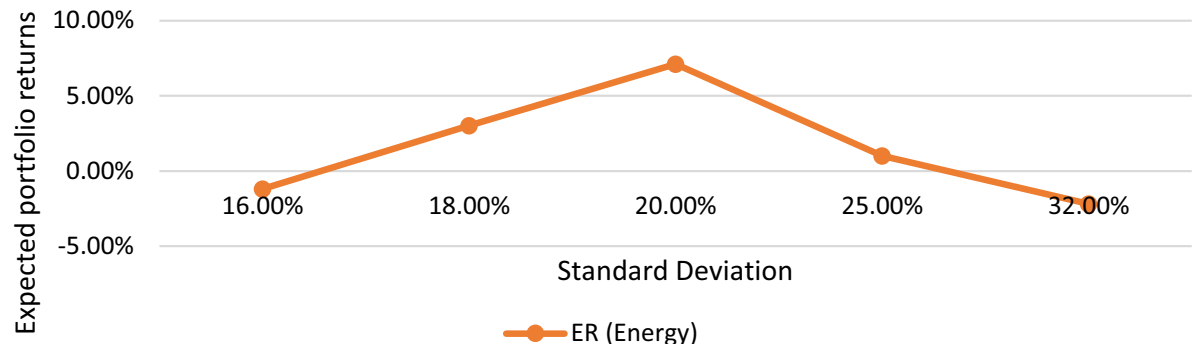

Standard Deviation

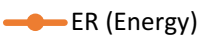

Fig. 1 Efficient portfolio for an energy commodities' futures portfolio 
Table 4 Descriptive statistics for energy commodity futures' portfolios providing mean, standard deviation and Sharpe ratios for Naïve and optimized Sharpe ratio of portfolios

\begin{tabular}{lcc}
\hline $\begin{array}{l}\text { Energy commodity } \\
\text { futures }\end{array}$ & $\begin{array}{l}\text { Naïve portfolio } \\
(1 / 5)\end{array}$ & $\begin{array}{l}\text { Optimized Sharpe } \\
\text { ratio }\end{array}$ \\
\hline Mean & $-16.72 \%$ & $9.60 \%$ \\
Standard deviation & $35.61 \%$ & $22.02 \%$ \\
Sharpe ratio & -0.485 & 0.411 \\
\hline
\end{tabular}

ratio results for the energy portfolio. The naïve portfolio is an equally weighted portfolio, with $20 \%$ of the weights given to each commodity futures in the energy portfolio. A high standard deviation and a negative return are observed due to the market dynamics for energy commodities in the past decade. The optimized Sharpe ratio shows that a $9.60 \%$ return is achieved for a standard deviation of $22 \%$ for the energy futures portfolio. The Sharpe ratio is calculated using a risk-free rate of return of $0.55 \%$ as the US Treasury note rate on July $31,2020$.

We next study the results of different commodity portfolios with and without diversification using energy futures. For each of the commodities' class, we find efficient frontier by conducting Markowitz Mean-Variance analysis, Optimize Sharpe ratio, and naïve portfolio analysis with and without diversification using energy futures.

Figure 2 plots the risk and return profiles of an agricultural commodity portfolio of rice, canola, wheat, soybean, and corn futures. The expected return of the agricultural portfolio is negative for all the risk levels. With the addition of energy futures in the portfolio, an improved return for the same risk is observed for each level of the risk considered to plot an efficient portfolio. The analysis shows that the energy future improves diversification by increasing the return in an agricultural commodity portfolio. An increase of about $500 \%$ is observed where the returns have been improved from-2\% to more than $8 \%$ with energy futures diversification.

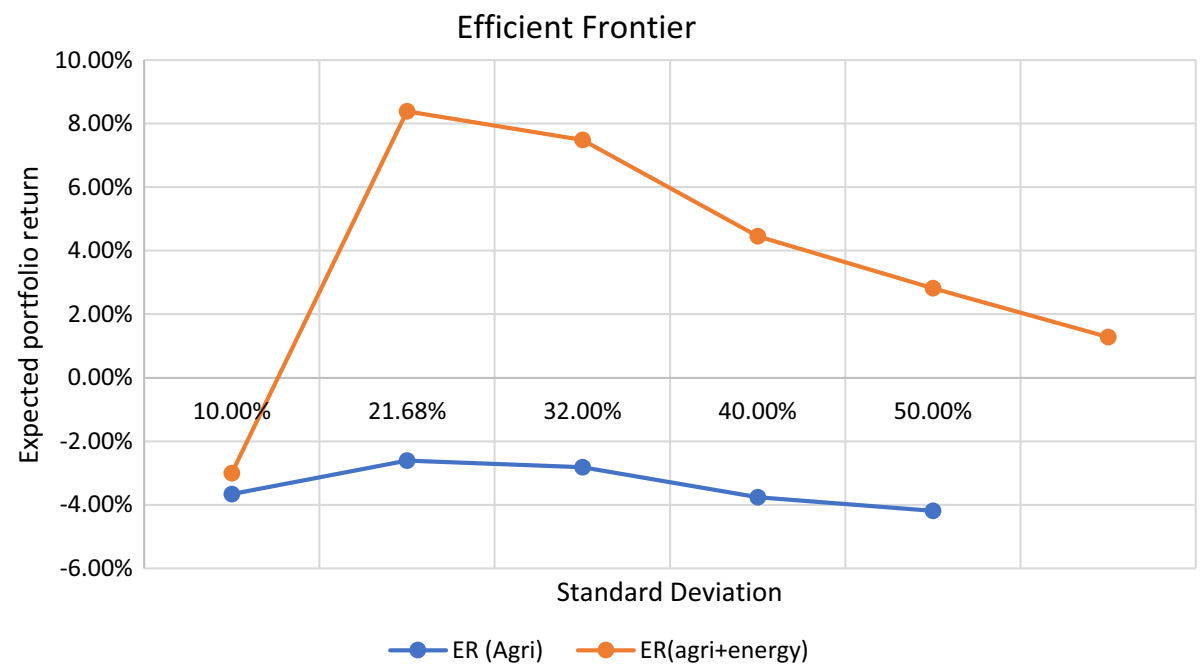

Fig. 2 Efficient frontier of a portfolio of agricultural commodity futures along with an energy commodity futures' diversified portfolio 
Table 5 Descriptive statistics for Agricultural commodity futures with and without energy commodity futures for portfolio diversification providing mean, standard deviation, and Sharpe ratios for Naïve and optimized Sharpe ratio of portfolios

\begin{tabular}{llllc}
\hline $\begin{array}{l}\text { Agricultural } \\
\text { commodities } \\
\text { futures }\end{array}$ & $\begin{array}{l}\text { Agricultural } \\
\text { futures only } \\
\text { Naïve portfolio } \\
(1 / 5)\end{array}$ & Agri + energy futures & Agri futures only & $\begin{array}{l}\text { Agri + energy } \\
\text { futures }\end{array}$ \\
\hline Mean & $-5.63 \%$ & $-11.18 \%$ & $\begin{array}{l}\text { Optimized } \\
\text { Sharpe ratio }\end{array}$ \\
Standard deviation & $34.17 \%$ & $27.54 \%$ & $-6.18 \%$ & $9.60 \%$ \\
Sharpe ratio & -0.18 & -0.43 & $110.63 \%$ & $22.02 \%$ \\
\hline
\end{tabular}

Table 5 provides analysis results for naïve portfolios and optimized Sharpe ratios for agricultural and agricultural and energy futures portfolios. It is observed that even though the naïve portfolio for agricultural futures provides negative returns, it performed better than the diversified equally weighted agricultural and energy futures portfolio. However, it can be seen that the agricultural and energy futures naïve portfolio had a lower risk compared to the agricultural futures portfolio. The Sharpe ratio results are not great in both cases, with an agricultural futures portfolio still having a better Sharpe ratio than the diversified naïve portfolio. The optimized Sharpe ratio results for the diversified portfolio are pretty good in comparison. The portfolio returns are increased from $-6 \%$ to $9.60 \%$, which is a more than $200 \%$ increase. The risk is reduced from 110 to $22 \%$ for the diversified energy futures portfolio, which is an $80 \%$ decrease in the risk due to the diversification. The results show that energy futures have a solid ability to diversify the risk and provide higher returns simultaneously for optimized Sharpe ratio and Markowitz Mean-Variance optimization.

Figure 3 and Table 6 provide a similar analysis for the portfolio of soft commodities and energy futures diversification of the soft commodities' portfolio. The risk and return profile with diversification show better returns for the same level of risk for up to the level of $30 \%$

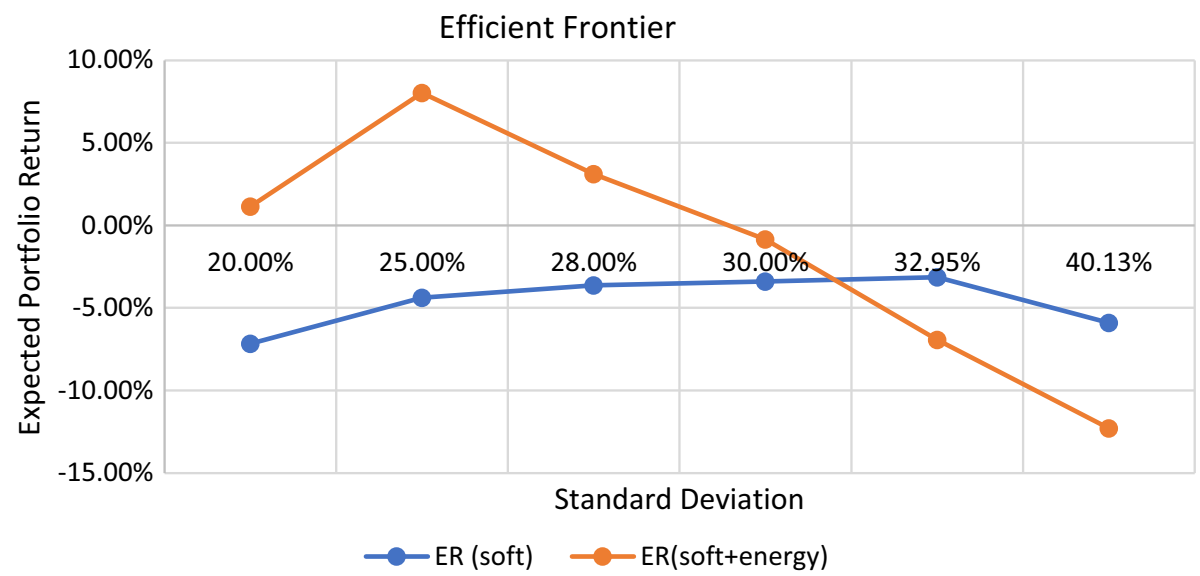

Fig. 3 Efficient frontier of a portfolio of Soft commodity futures along with an energy commodity futures' diversified portfolio 
Table 6 Descriptive statistics for Soft commodity futures with and without energy commodity futures for portfolio diversification providing mean, standard deviation, and Sharpe ratios for Naïve and optimized Sharpe ratio of portfolios

\begin{tabular}{|c|c|c|c|c|}
\hline \multirow[t]{2}{*}{$\begin{array}{l}\text { Soft commodities } \\
\text { futures }\end{array}$} & $\begin{array}{l}\text { Soft commodity } \\
\text { futures only }\end{array}$ & $\begin{array}{l}\text { Soft + energy } \\
\text { commodity } \\
\text { futures }\end{array}$ & $\begin{array}{l}\text { Soft commodity } \\
\text { futures only }\end{array}$ & $\begin{array}{l}\text { Soft + energy } \\
\text { commodity } \\
\text { futures }\end{array}$ \\
\hline & $\begin{array}{l}\text { Naïve portfolio } \\
(1 / 4)\end{array}$ & $\begin{array}{l}\text { Naïve portfolio } \\
(1 / 9)\end{array}$ & $\begin{array}{l}\text { Optimized Sharpe } \\
\text { ratio }\end{array}$ & $\begin{array}{l}\text { Optimized } \\
\text { Sharpe ratio }\end{array}$ \\
\hline Mean & $-9.05 \%$ & $-13.31 \%$ & $-3.13 \%$ & $9.60 \%$ \\
\hline Standard deviation & $19.22 \%$ & $22.88 \%$ & $32.95 \%$ & $22.02 \%$ \\
\hline Sharpe ratio & -0.499 & -0.606 & -0.112 & 0.411 \\
\hline
\end{tabular}

in terms of standard deviation. The Markowitz mean-variance analysis shows that for up to $30 \%$ standard deviation levels, the diversification of soft commodity futures portfolio with energy futures provides better returns when compared with the portfolio of soft commodity futures. However, diversification does not provide acceptable returns when the level of risk is beyond $30 \%$. In Table 6, we can see that the naïve diversification using energy futures also does not provide better results for soft commodity portfolio. The diversification results using energy futures in the portfolio of soft commodities are better when the Sharpe ratio is optimized for the portfolios. The return in the diversified portfolio using energy commodities is $400 \%$ more than the portfolio without energy commodities' futures when optimizing is done using the Sharpe ratio. In addition to a significant increase in return, the risk in the diversified portfolio using energy derivatives has also decreased from the original risk of around $33 \%$ to $22 \%$. The decrease in the risk level is a reduction of about one third of the risk level. Therefore, we conclude that energy futures diversify the soft commodity futures when the Sharpe ratio is optimized and for most risk levels of Markowitz mean-variance analysis.

Next, we analyze the diversification results of the energy futures on the metal commodities portfolio that considers gold, silver, copper, uranium, and iron. We can see that the returns from the diversified portfolio for Markowitz mean-variance analysis are higher than those of the metal commodity portfolio for the same risk levels. That is, the diversified portfolios provide better returns for the same risk level, as can be seen in Fig. 4. The diversification using naïve portfolios does not favor the energy futures, and the results for return, standard deviation, and Sharpe ratio are worse than the non-diversified portfolio. In addition to that, Table 7 also describes the results for the optimized Sharpe ratio for both diversified and non-diversified portfolios. The diversified metal commodity portfolio with energy futures not only provides better returns but also reduces the risk and hence a better Sharpe ratio.

We also analyze a portfolio of all three commodity classes that we have used in the above analysis. We consider a commodity portfolio of agricultural, metal, and soft commodities and study the diversification results using energy futures. The Markowitz mean-variance analysis is obtained by solving a problem of maximizing return subject to a given risk level measure in terms of the standard deviation of the portfolio. The results are plotted in Fig. 5. It is observed that the diversified portfolio using energy futures provide overall better returns for the same level of risks than the all commodity portfolio. The Sharpe ratio optimization results are also shown to be improved because of an increase in the return and reduction in the risk of a diversified portfolio. Therefore, we observe that in all the cases, the energy 


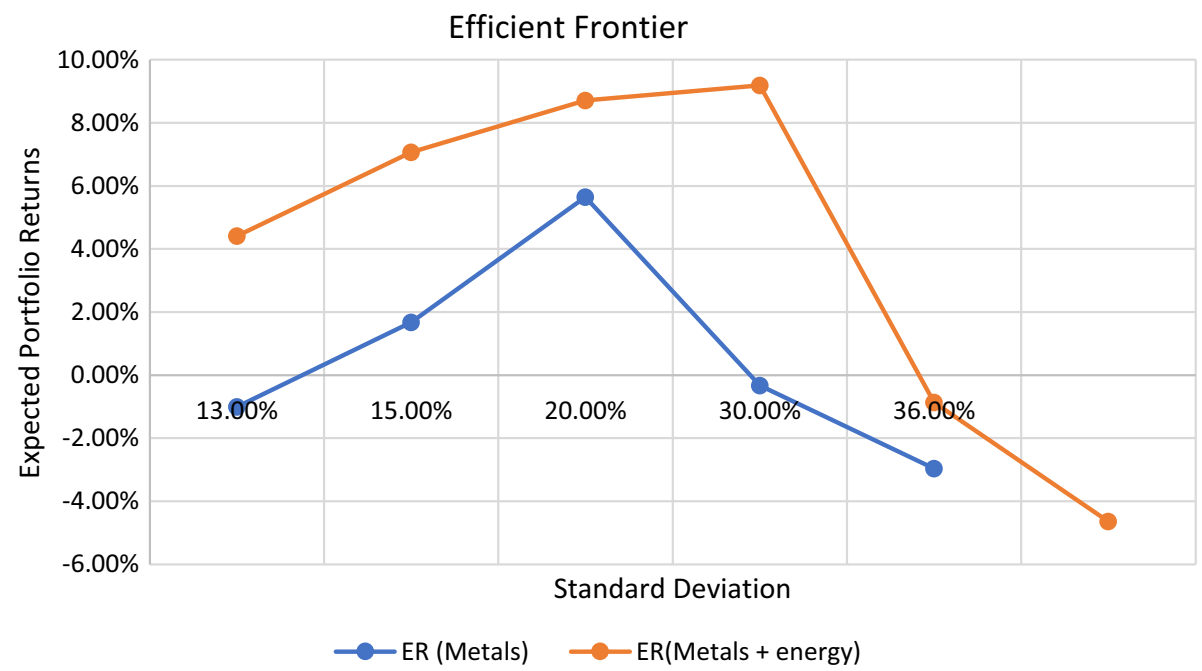

Fig. 4 Efficient frontier of a portfolio of Metal commodity futures along with an energy commodity futures' diversified portfolio

Table 7 Descriptive statistics for Metal commodity futures with and without energy commodity futures for portfolio diversification providing mean, standard deviation, and Sharpe ratios for Naïve and optimized Sharpe ratio of portfolios

\begin{tabular}{lllll}
\hline $\begin{array}{l}\text { Metal } \\
\text { commodities } \\
\text { futures }\end{array}$ & $\begin{array}{l}\text { Metal commodity } \\
\text { futures only }\end{array}$ & $\begin{array}{l}\text { Metal + energy } \\
\text { futures }\end{array}$ & $\begin{array}{l}\text { Metal commodity } \\
\text { futures only }\end{array}$ & $\begin{array}{l}\text { Metal + } \\
\text { energy } \\
\text { futures }\end{array}$ \\
& Naïve portfolio (1/5) & $\begin{array}{l}\text { Naïve portfolio } \\
(1 / 10)\end{array}$ & $\begin{array}{l}\text { Optimized Sharpe } \\
\text { ratio }\end{array}$ & $\begin{array}{l}\text { Optimized } \\
\text { Sharpe ratio }\end{array}$ \\
\hline $\begin{array}{l}\text { Mean } \\
\begin{array}{l}\text { Standard } \\
\text { deviation }\end{array}\end{array}$ & $-4.36 \%$ & $-10.54 \%$ & $5.71 \%$ & $8.11 \%$ \\
$\begin{array}{l}\text { Sharpe ratio } \\
\text { Sharion }\end{array}$ & -0.334 & $20.41 \%$ & $19.93 \%$ & $16.21 \%$ \\
\hline
\end{tabular}

futures provide better optimized Sharpe ratios and improved return for the same level of risk for Markowitz mean-variance analysis (Table 8).

In the following two sections, we break our data into pre-covid 19 periods from Jan 2011 to March 11, 2020, and covid 19 periods from March 11, 2020, to July 2020. The covid 19 periods is selected as one after March 11, 2020, when World Health Organization (WHO) declared covid 19 a pandemic. Finally, we study the portfolio optimization results for the two time periods mentioned above to validate our results or further explore portfolio optimization.

\subsection{Commodity futures diversification for Pre-Covid 19 period}

The section provides results for the portfolio optimization of the chosen commodity futures classes: agricultural commodities, soft commodities, metal commodities, and a portfolio of 


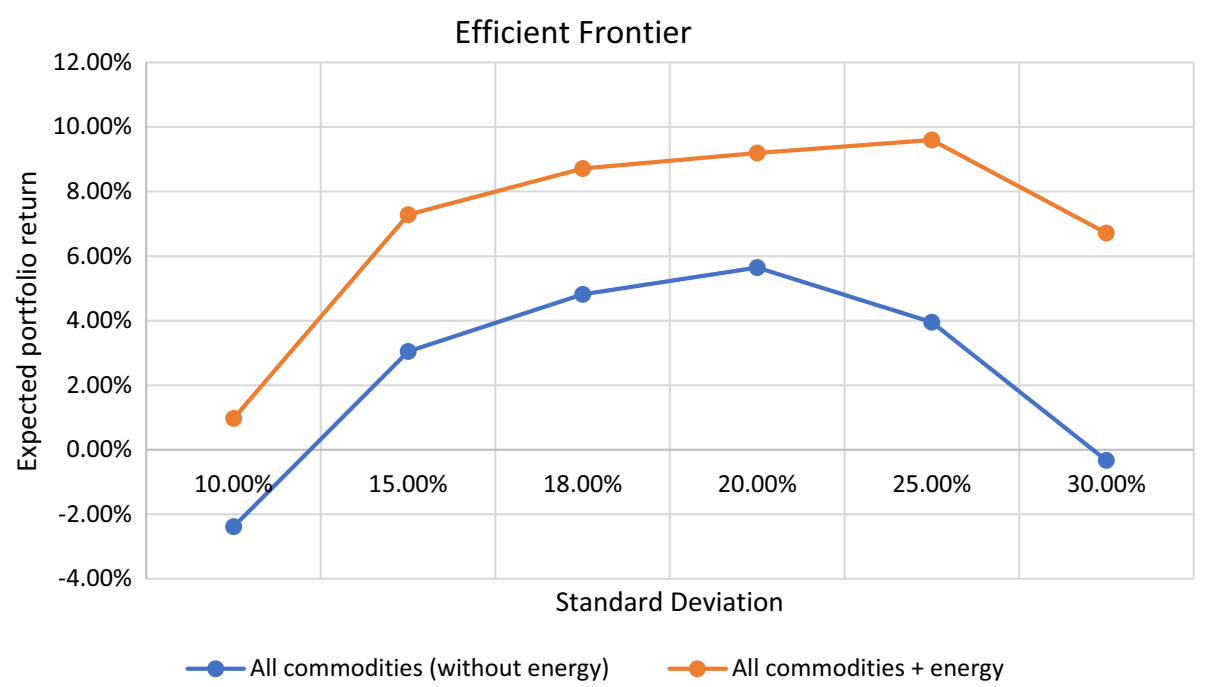

Fig. 5 Efficient frontier of a portfolio of all commodity futures along with an energy commodity futures' diversified portfolio

Table 8 Descriptive statistics for All commodity futures with and without energy commodity futures for portfolio diversification providing mean, standard deviation, and Sharpe ratios for Naïve and optimized Sharpe ratio of portfolios

\begin{tabular}{|c|c|c|c|c|}
\hline \multirow[t]{2}{*}{$\begin{array}{l}\text { All } \\
\text { commodities } \\
\text { futures }\end{array}$} & $\begin{array}{l}\text { All } \\
\text { commodity } \\
\text { futures only }\end{array}$ & $\begin{array}{l}\text { All + energy } \\
\text { commodity futures }\end{array}$ & $\begin{array}{l}\text { All } \\
\text { commodity } \\
\text { futures only }\end{array}$ & $\begin{array}{l}\text { All + energy } \\
\text { commodity } \\
\text { futures }\end{array}$ \\
\hline & $\begin{array}{l}\text { Naïve portfolio } \\
(1 / 14)\end{array}$ & $\begin{array}{l}\text { Naïve portfolio } \\
(1 / 19)\end{array}$ & $\begin{array}{l}\text { Optimized Sharpe } \\
\text { ratio }\end{array}$ & $\begin{array}{l}\text { Optimized } \\
\text { Sharpe ratio }\end{array}$ \\
\hline Mean & $-6.15 \%$ & $-8.94 \%$ & $5.71 \%$ & $8.11 \%$ \\
\hline Standard deviation & $16.61 \%$ & $17.46 \%$ & $19.93 \%$ & $16.21 \%$ \\
\hline Sharpe ratio & -0.404 & -0.543 & 0.259 & 0.466 \\
\hline
\end{tabular}

all commodities futures with and without energy futures derivatives. Risk and return profiles of energy commodity futures during the pre-covid 19 periods are shown in Fig. 6. We solve for the maximized expected return of the portfolio for a given level of risk as defined by the standard deviation of the portfolio. The wealth is fully invested in the portfolio; that is, the sum of the weights in a portfolio's assets is 1 . It is observed that the return of the portfolio for energy-only commodities futures starts decreasing when the risk goes beyond a certain level. Overall, the returns are also low from the portfolio showing that these instruments' investment is tricky before the covid period. A high standard deviation and a negative return are observed due to the market dynamics for energy commodities in the past decade. The results for naïve and optimized Sharpe ratio portfolios are provided in Table 9. The results show that the naïve portfolio, where the weights are equally distributed between the assets, provides a negative return of $9.44 \%$ for a risk measure of $21.24 \%$. However, the results improve for the optimized Sharpe ratio portfolio where a return of $10.78 \%$ is observed for 


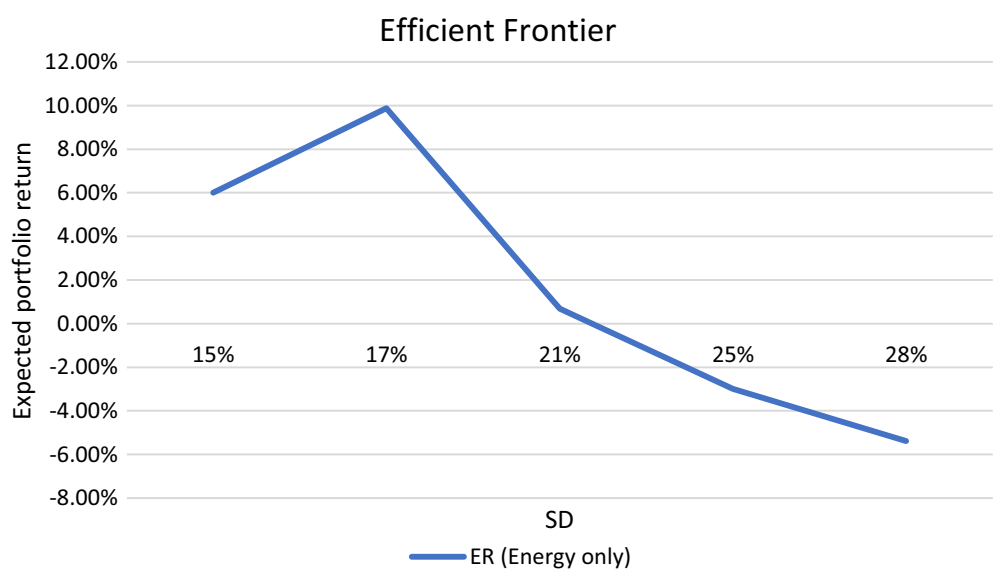

Fig. 6 Efficient frontier of a portfolio of energy commodity futures Pre covid 19 Jan 2011-March 11, 2020

Table 9 Descriptive statistics for energy commodity futures' portfolios providing mean, standard deviation, and Sharpe ratios for Naïve and optimized Sharpe ratio of portfolios diversification before Covid 19 (Jan 2011 to March 2020)

\begin{tabular}{lll}
\hline $\begin{array}{l}\text { Energy commodity } \\
\text { futures }\end{array}$ & $\begin{array}{l}\text { Naïve portfolio } \\
(1 / 5)\end{array}$ & $\begin{array}{l}\text { Optimized Sharpe } \\
\text { ratio }\end{array}$ \\
\hline Mean & $-9.44 \%$ & $10.78 \%$ \\
Standard deviation & $21.24 \%$ & $17.55 \%$ \\
Sharpe ratio & -0.47 & 0.58
\end{tabular}

a risk measure of $17.55 \%$, providing the optimized Sharpe ratio of 0.58 . The Sharpe ratio is calculated using a risk-free rate of return of $0.55 \%$ as the US Treasury note rate on July 31 , 2020.

Next, we study the agricultural commodity futures portfolio with and without the inclusion of energy derivatives futures. Figure 7 plots the efficient frontier for both portfolios. The returns from agricultural commodities for the pre-covid period, even though increasing, is negative for all the risk levels. The inclusion of energy commodities futures improves the result for low-risk levels, and returns decrease over increased risk measures. Table 10 further clears the results for both with and without the inclusion of energy derivatives futures. The results for naïve portfolios show that even though the return in a diversified portfolio worsens, the portfolio risk decreases when the energy commodity futures are included in the portfolio of agricultural commodity futures. Such a result is understandable because naïve portfolios equally distribute weights in all the assets without considering the risk and return of individual assets. The optimized Sharpe ratio portfolio clearly shows better results for the energy commodities futures' diversified portfolio. The return improved from $-1.27 \%$ to $10.78 \%$ that is approximately a $948 \%$ increase. The risk as measured by standard deviation also decreases from $28.39 \%$ to $17.55 \%$, which is a $38 \%$ decrease. The overall optimized Sharpe ratio is also improved from -0.064 to 0.583 .

Figure 8 provides a graphical representation of risk and return profiles, efficient frontier, of soft commodity futures portfolio and soft commodity futures portfolio with the inclusion of energy commodity futures. Energy commodities futures' inclusive portfolio provides a better return for a given standard deviation than a non, energy commodities diversified portfolio 


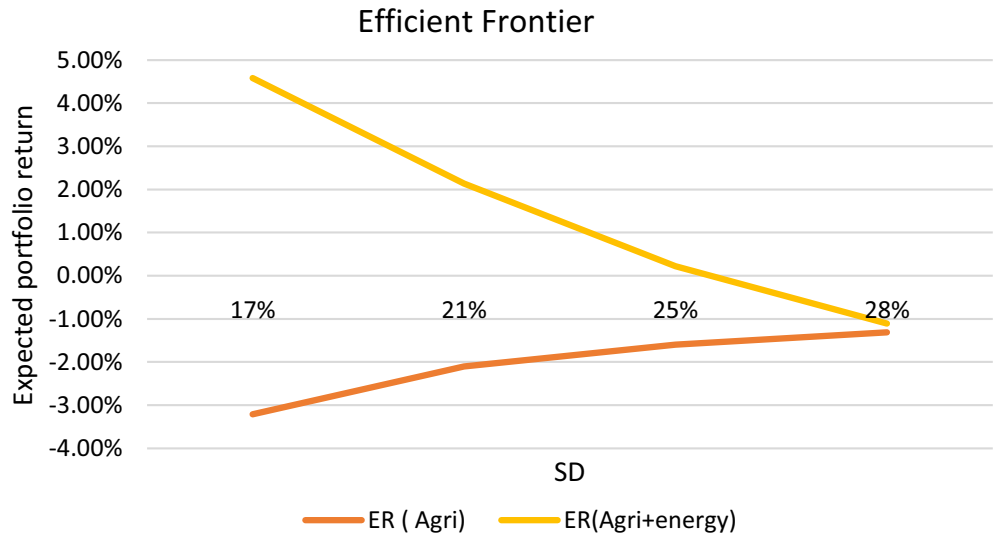

Fig. 7 Efficient frontier of a portfolio of agricultural commodity futures along with an energy commodity futures' diversified portfolio Pre covid 19 Jan 2011-March 11, 2020

Table 10 Descriptive statistics for Agricultural commodity futures with and without energy commodity futures for portfolio diversification before Covid 19 (Jan 2011-March 2020) providing mean, standard deviation, and Sharpe ratios for Naïve and optimized Sharpe ratio of portfolios

\begin{tabular}{lllll}
\hline $\begin{array}{l}\text { Agricultural } \\
\text { commodities } \\
\text { futures }\end{array}$ & $\begin{array}{l}\text { Agricultural } \\
\text { futures only } \\
\text { Naïve portfolio } \\
(1 / 5)\end{array}$ & Agri + energy futures & Agri futures only & $\begin{array}{l}\text { Agri + energy } \\
\text { futures }\end{array}$ \\
\hline Mean & $-5.29 \%$ & $-7.36 \%$ & $\begin{array}{l}\text { Optimized } \\
\text { Sharpe ratio }\end{array}$ \\
Standard deviation & $17.66 \%$ & $14.84 \%$ & $-1.27 \%$ & $10.78 \%$ \\
Sharpe ratio & -0.33 & -0.53 & $28.39 \%$ & $17.55 \%$ \\
\hline
\end{tabular}

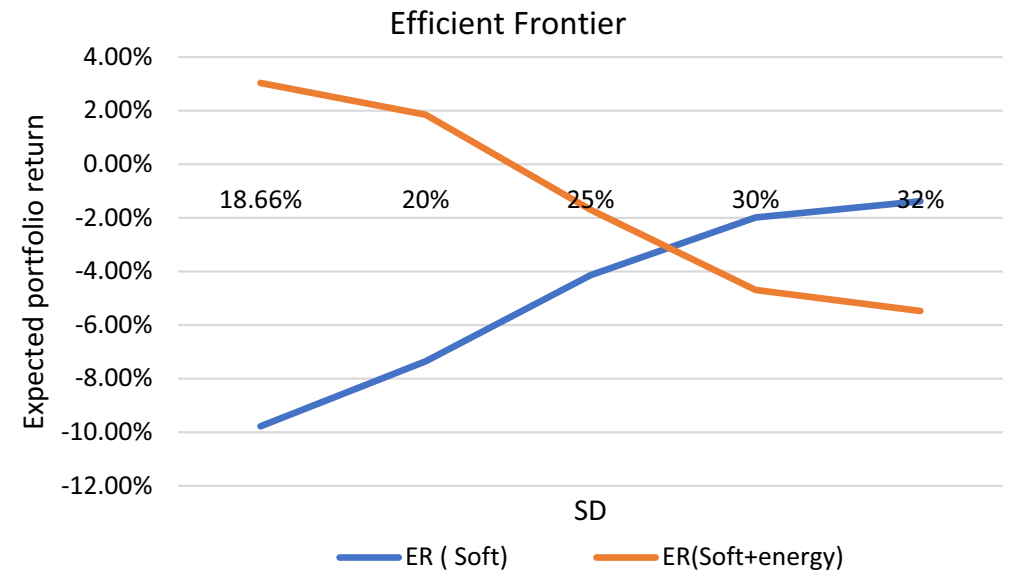

Fig. 8 Efficient frontier of a portfolio of soft commodity futures along with an energy commodity futures' diversified portfolio Pre covid 19 Jan 2011-March 11, 2020 
for up to a risk level of around $28 \%$. The maximum return for any level of risk is around $2 \%$ for soft commodity futures for the data set from Jan 2011 to March 11, 2020 (pre-covid 19 timelines). When energy commodities were added to the existing portfolio, the maximum return from the diversified portfolio was increased to around $3 \%$ from $-9.78 \%$. Table 11 shows that the naïve portfolio, inclusive of energy commodity derivatives, decreases the portfolio's risk while lowering the portfolio's return compared with a non-diversified portfolio of soft commodity futures. The diversification results in the optimized Sharpe ratio show a significant improvement in the diversified portfolio from a non-diversified portfolio. The Sharpe ratio improves from -0.055 to 0.583 , increasing around $1160 \%$ while simultaneously increasing return and decreasing the standard deviation of the portfolio.

Further, we study the metal commodities futures portfolio between Jan 2011 to March 11, 2020 (pre-crisis period). The efficient portfolio shows that the return of an energy derivatives diversified portfolio is lower than those without energy derivatives diversification for a return above $19 \%$ (Fig. 9). Even with a poor risk-return profile of diversified energy and metal commodities futures' portfolios, the Sharpe ratio optimization provides much better results,

Table 11 Descriptive statistics for Soft commodity futures with and without energy commodity futures for portfolio diversification before Covid 19 (Jan 2011 to March 2020) providing mean, standard deviation, and Sharpe ratios for Naïve and optimized Sharpe ratio of portfolios

\begin{tabular}{lllll}
\hline $\begin{array}{l}\text { Soft } \\
\text { commodities } \\
\text { futures }\end{array}$ & $\begin{array}{l}\text { Soft commodity } \\
\text { futures only }\end{array}$ & $\begin{array}{l}\text { Soft + energy } \\
\text { commodity } \\
\text { futures }\end{array}$ & $\begin{array}{l}\text { Soft commodity } \\
\text { futures only }\end{array}$ & $\begin{array}{l}\text { Soft + energy } \\
\text { commodity } \\
\text { futures }\end{array}$ \\
& $\begin{array}{l}\text { Naïve portfolio } \\
(1 / 4)\end{array}$ & $\begin{array}{l}\text { Naïve portfolio } \\
(1 / 9)\end{array}$ & $\begin{array}{l}\text { Optimized Sharpe } \\
\text { ratio }\end{array}$ & $\begin{array}{l}\text { Optimized } \\
\text { Sharpe ratio }\end{array}$ \\
\hline $\begin{array}{l}\text { Mean } \\
\begin{array}{l}\text { Standard } \\
\text { deviation }\end{array}\end{array}$ & $-10.02 \%$ & $-9.70 \%$ & $-1.24 \%$ & $10.78 \%$ \\
Sharpe ratio & -0.556 & $15.79 \%$ & $32.50 \%$ & $17.55 \%$ \\
\hline
\end{tabular}

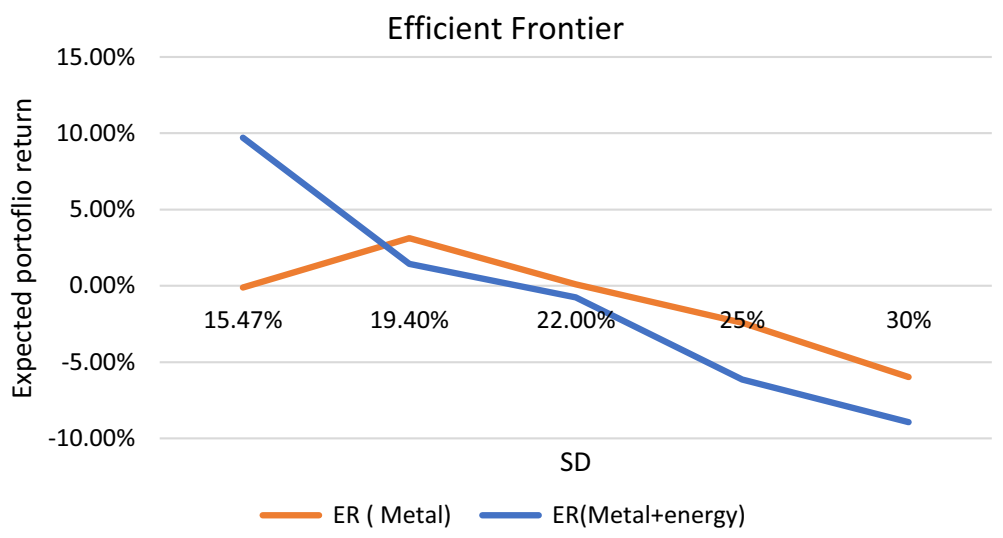

Fig. 9 Efficient frontier of a portfolio of metal commodity futures along with an energy commodity futures' diversified portfolio Pre covid 19 Jan 2011-March 11, 2020 
Table 12 Descriptive statistics for Metal commodity futures with and without energy commodity futures for portfolio diversification before Covid 19 (Jan 2011 to March 2020) providing mean, standard deviation, and Sharpe ratios for Naïve and optimized Sharpe ratio of portfolios

\begin{tabular}{lllll}
\hline $\begin{array}{l}\text { Metal } \\
\text { commodities } \\
\text { futures }\end{array}$ & $\begin{array}{l}\text { Metal } \\
\text { commodity } \\
\text { futures only } \\
\text { Naïve portfolio } \\
(1 / 5)\end{array}$ & $\begin{array}{l}\text { Metal + energy } \\
\text { futures } \\
\text { Naïve portfolio } \\
(1 / 10)\end{array}$ & $\begin{array}{l}\text { Metal } \\
\text { commodity } \\
\text { futures only } \\
\text { Optimized Sharpe } \\
\text { ratio }\end{array}$ & $\begin{array}{l}\text { Metal + energy } \\
\text { futures }\end{array}$ \\
\hline $\begin{array}{l}\text { Mean } \\
\begin{array}{l}\text { Standard } \\
\text { deviation }\end{array}\end{array}$ & $-8.15 \%$ & $-8.80 \%$ & $3.12 \%$ & $9.71 \%$ \\
Sharpe ratio & $14.24 \%$ & $13.69 \%$ & $19.40 \%$ & $15.47 \%$ \\
\hline
\end{tabular}

as shown in Table 12 . The return on the portfolio is increased by $211 \%$, while simultaneously decreasing the risk by $20 \%$. The optimized Sharpe ratio is also increased from 0.133 to 0.592 .

Lastly, we discuss the portfolio of all commodities addressed in the analysis of portfolio diversification using energy commodities. Figure 10 provides a graphical representation of the risk and return profiles for all commodity futures portfolios, and an energy commodities futures diversified portfolio. The return is higher on the diversified portfolio for below $19 \%$ risk. The difference between the return on both portfolios decreases with an increase in the standard deviation. In Table 13, we provide the results for naïve and optimized portfolios. It is observed that both risk and return are slightly worsened when the energy commodities futures have been added to an all commodities futures portfolio in a naïve portfolio. However, the results for optimized Sharpe ratio for all commodities, including energy commodities futures, have improved significantly. The return on the diversified portfolio is $9.71 \%$ compared to

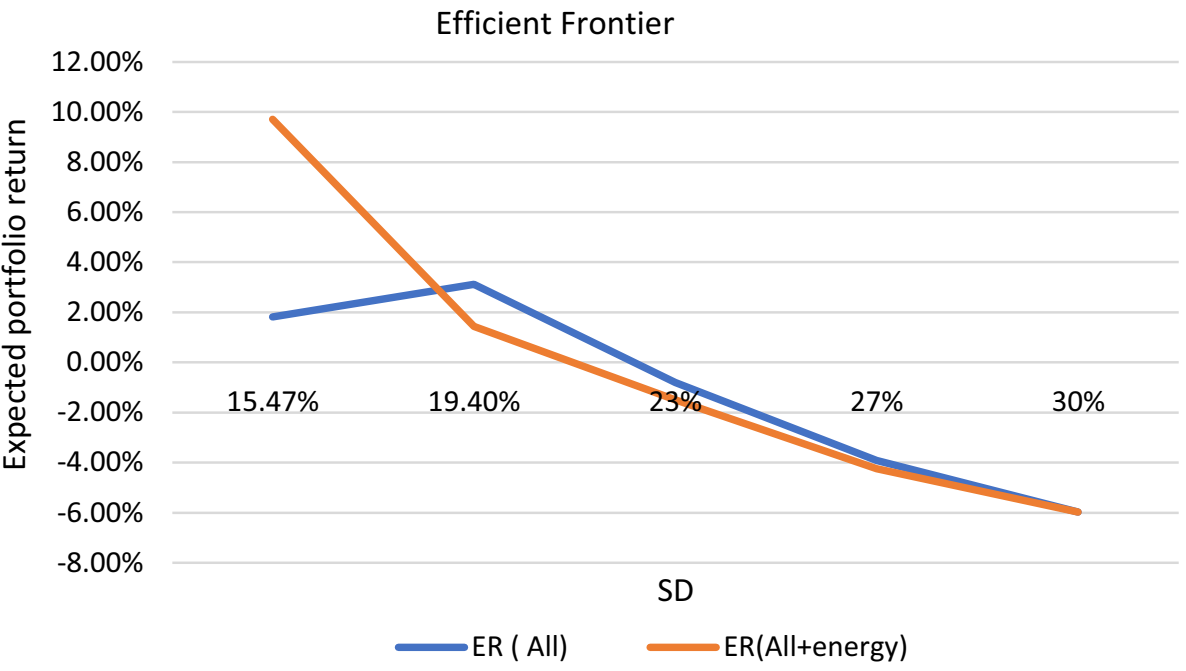

Fig. 10 Efficient frontier of a portfolio of all commodity futures along with an energy commodity futures' diversified portfolio Pre covid 19 Jan 2011-March 11, 2020 
Table 13 Descriptive statistics for All commodity futures with and without energy commodity futures for portfolio diversification before Covid 19 (Jan 2011 to March 2020) providing mean, standard deviation, and Sharpe ratios for Naïve and optimized Sharpe ratio of portfolios

\begin{tabular}{lllll}
\hline $\begin{array}{l}\text { All } \\
\text { commodities } \\
\text { futures }\end{array}$ & $\begin{array}{l}\text { All } \\
\text { commodity } \\
\text { futures only } \\
\text { Naïve portfolio } \\
(1 / 14)\end{array}$ & $\begin{array}{l}\text { All + energy } \\
\text { commodity futures }\end{array}$ & $\begin{array}{l}\text { All } \\
\text { commodity } \\
\text { futures only } \\
(1 / 19)\end{array}$ & $\begin{array}{l}\text { All + energy } \\
\text { commodity } \\
\text { futures }\end{array}$ \\
\hline Mean & $-7.66 \%$ & $-8.13 \%$ & $\begin{array}{l}\text { Optimized Sharpe } \\
\text { ratio }\end{array}$ & $\begin{array}{l}\text { Optimized } \\
\text { Sharpe ratio }\end{array}$ \\
Standard deviation & $10.91 \%$ & $10.93 \%$ & $3.12 \%$ & $9.71 \%$ \\
Sharpe ratio & -0.752 & -0.794 & $19.40 \%$ & $15.47 \%$ \\
\hline
\end{tabular}

a non-diversified portfolio with a return of $3.12 \%$. A decrease of $20 \%$ is observed in the risk of the portfolio also. The observation shows that the results are improved when energy commodities are added to a diversified commodities futures portfolio before the crisis.

\subsection{Commodity futures diversification for Covid 19 (March 11, 2020-July 2020)}

This section analyzes portfolio optimization results for our chosen four classes of commodities' futures by including energy commodity futures after breaking the data into the pandemic period from March 11, 2020, to July 2020. We are using March 11, 2020, to break the data into the pre-crisis period because on this date, WHO announced Covid 19 as a pandemic. The analysis in the section is from March 11, 2020, till the end of the dataset we are investigating. In Fig. 11, risk and return profiles of energy commodity futures are provided for the

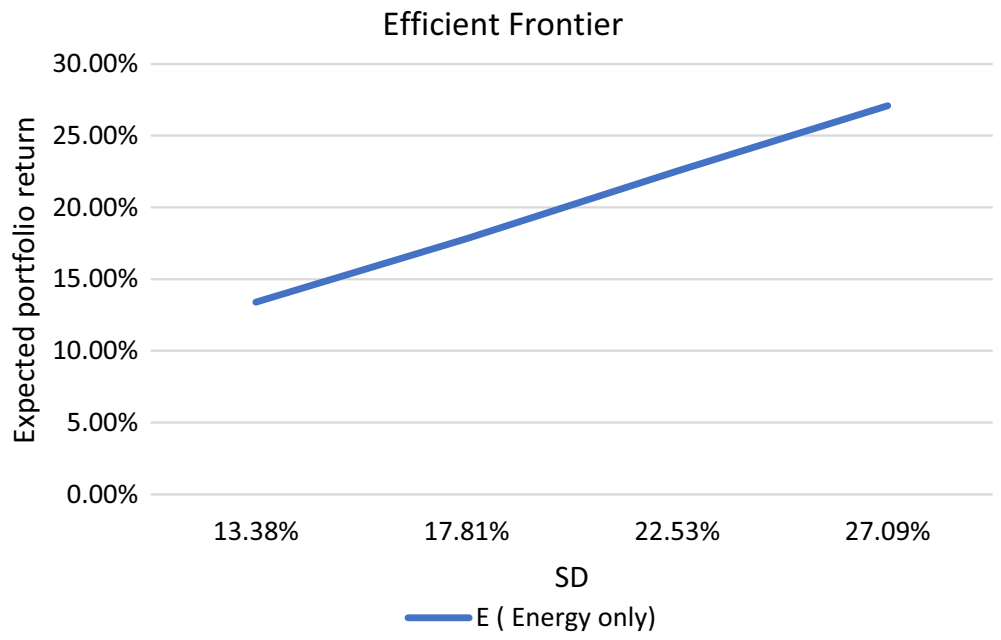

Fig. 11 Efficient frontier of a portfolio of energy commodity futures portfolio March 11, 2020, to July 2020 (Covid 19) 
Table 14 Descriptive statistics for energy commodity futures' portfolios providing mean, standard deviation, and Sharpe ratios for Naïve and optimized Sharpe ratio of portfolios diversification during Covid 19 (March 11, 2020, to July 2020)

\begin{tabular}{lll}
\hline $\begin{array}{l}\text { Energy commodity } \\
\text { futures }\end{array}$ & $\begin{array}{l}\text { Naïve portfolio } \\
(1 / 5)\end{array}$ & $\begin{array}{l}\text { Optimized Sharpe } \\
\text { ratio }\end{array}$ \\
\hline Mean & $-65.35 \%$ & $27.09 \%$ \\
Standard deviation & $78.98 \%$ & $48.78 \%$ \\
Sharpe ratio & -0.834 & 0.544 \\
\hline
\end{tabular}

covid 19 data. It can be seen that the expected return increases as we increase the risk tolerance as measured by the standard deviation of the portfolios. Table 14 further investigates naïve and optimized Sharpe the ratio for energy only commodity futures portfolio. It can be seen that for a naïve portfolio, the Sharpe ratio is -0.834 , where the risk is extremely high at $78.89 \%$. However, the Sharpe ratio optimization provides reasonably good results. The expected returns are at $27.09 \%$ for an optimized Sharpe ratio of 0.544 with a risk of nearly $49 \%$.

The first commodities' futures' portfolio that we consider consists of five agricultural commodities futures for the dataset after covid 19 was declared a pandemic. Figure 12 shows a decrease in the expected portfolio returns as we increase the standard deviation. But when we add the energy commodities futures in the existing agricultural commodities futures' portfolio, the return rises significantly for the same level of risk. The return is increased by a good $1177 \%$ for $35 \%$ risk tolerance in the portfolio from a mere $0.22 \%$ in the non-diversified portfolio to $26.11 \%$ in the case of a diversified portfolio. Table 15 provides both naïve and optimized Sharpe ratio results for diversified and non-diversified portfolios for data on covid 19. The effects for agricultural and energy commodity portfolios worsen in the case of naïve portfolios. This is because equal weights have been assigned to all assets, which may not provide the best results. On the other hand, the portfolio optimization in the optimized Sharpe ratio slightly improves when energy derivatives have been added to the existing portfolio.

Next, we study the portfolio optimization results for soft commodities in the data for the covid 19 periods. The efficient frontier for soft commodities portfolio and soft commodities plus energy commodities futures portfolio are presented in Fig. 13. The results are slightly

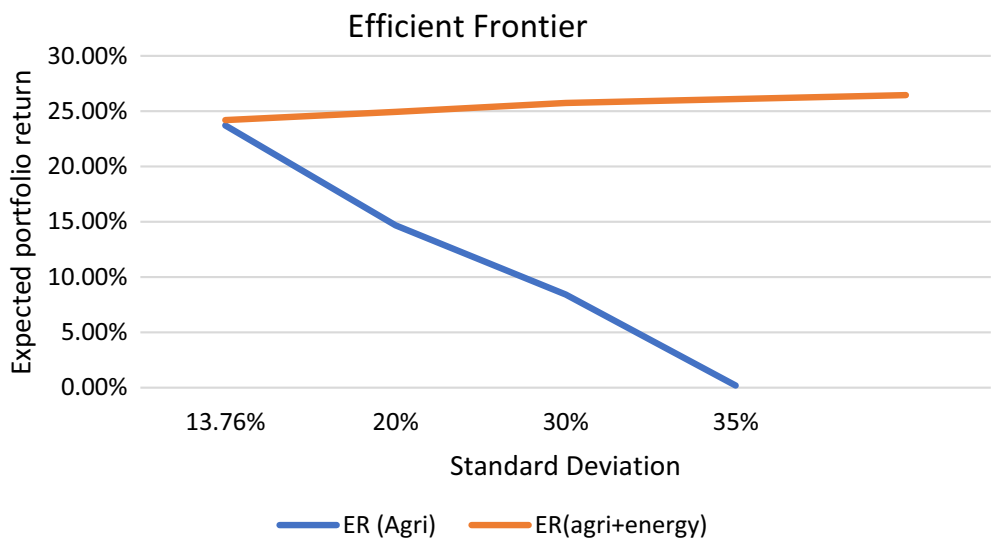

Fig. 12 Efficient frontier of a portfolio of agricultural commodity futures along with an energy commodity futures' diversified portfolio March 11, 2020, to July 2020 (Covid 19) 
Table 15 Descriptive statistics for Agricultural commodity futures with and without energy commodity futures for portfolio diversification during Covid 19 (March 11, 2020, to July 2020) providing mean, standard deviation, and Sharpe ratios for Naïve and optimized Sharpe ratio of portfolios

\begin{tabular}{|c|c|c|c|c|}
\hline \multirow{2}{*}{$\begin{array}{l}\text { Agricultural } \\
\text { commodities } \\
\text { futures }\end{array}$} & $\begin{array}{l}\text { Agricultural } \\
\text { futures only }\end{array}$ & Agri + energy futures & Agri futures only & $\begin{array}{l}\text { Agri + energy } \\
\text { futures }\end{array}$ \\
\hline & $\begin{array}{l}\text { Naïve portfolio } \\
(1 / 5)\end{array}$ & Naïve portfolio $(1 / 10)$ & $\begin{array}{l}\text { Optimized Sharpe } \\
\text { ratio }\end{array}$ & $\begin{array}{l}\text { Optimized } \\
\text { Sharpe ratio }\end{array}$ \\
\hline Mean & $-13.47 \%$ & $-43.79 \%$ & $23.70 \%$ & $23.98 \%$ \\
\hline Standard deviation & $22 \%$ & $46.54 \%$ & $13.76 \%$ & $13.26 \%$ \\
\hline Sharpe ratio & -0.637 & -0.953 & 1.68 & 1.77 \\
\hline
\end{tabular}

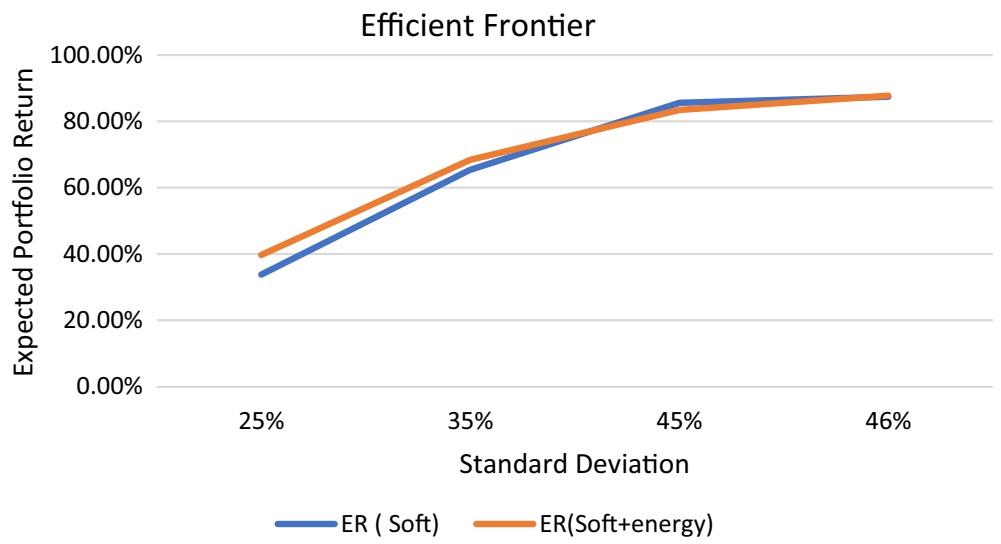

Fig. 13 Efficient frontier of a portfolio of soft commodity futures along with an energy commodity futures' diversified portfolio March 11, 2020, to July 2020 (Covid 19)

better for the soft commodities plus energy commodities futures portfolios for risk level below $45 \%$ and are almost the same afterward. Tables 16 and 17 compares both portfolios against two measures of optimization: Naïve portfolios and Optimized Sharpe ratios. The naïve portfolio results worsen when soft commodities are added to the portfolio. When the Sharpe ratio is used as an optimization measure, the expected return for a diversified portfolio decreases while reducing the standard deviation. The reduction in the risk provided a better Sharpe ratio for the diversified portfolio. A slight increase of $3.2 \%$ is seen in the Sharpe ratio for soft and energy commodities futures portfolios.

The results for metal commodity futures portfolios and all commodity futures portfolios are provided in Figs. 14 and 15 and Tables 18 and 19. The efficient frontiers for both the portfolios show that adding energy commodities derivatives to metal and all commodities portfolios do not change the results. The Tables also show that there is no to minimal change is observed in the two cases. We discuss all the cases in our next section on the discussion. 
Table 16 Descriptive statistics for Soft commodity futures with and without energy commodity futures for portfolio diversification during Covid 19 (March 11, 2020, to July 2020) providing mean, standard deviation, and Sharpe ratios for Naïve and optimized Sharpe ratio of portfolios

\begin{tabular}{|c|c|c|c|c|}
\hline $\begin{array}{l}\text { Soft } \\
\text { commodities } \\
\text { futures }\end{array}$ & $\begin{array}{l}\text { Soft commodity } \\
\text { futures only }\end{array}$ & $\begin{array}{l}\text { Soft + energy } \\
\text { commodity } \\
\text { futures }\end{array}$ & $\begin{array}{l}\text { Soft commodity } \\
\text { futures only }\end{array}$ & $\begin{array}{l}\text { Soft + energy } \\
\text { commodity } \\
\text { futures }\end{array}$ \\
\hline & $\begin{array}{l}\text { Naïve portfolio } \\
(1 / 4)\end{array}$ & $\begin{array}{l}\text { Naïve portfolio } \\
(1 / 9)\end{array}$ & $\begin{array}{l}\text { Optimized Sharpe } \\
\text { ratio }\end{array}$ & $\begin{array}{l}\text { Optimized } \\
\text { Sharpe ratio }\end{array}$ \\
\hline Mean & $13.13 \%$ & $-30.47 \%$ & $81.42 \%$ & $75.30 \%$ \\
\hline $\begin{array}{l}\text { Standard } \\
\text { deviation }\end{array}$ & $23.97 \%$ & $46.87 \%$ & $42.73 \%$ & $38.34 \%$ \\
\hline Sharpe ratio & 0.525 & -0.662 & 1.89 & 1.95 \\
\hline
\end{tabular}

Table 17 Descriptive statistics for Metal commodity futures with and without energy commodity futures for portfolio diversification during Covid 19 (March 11, 2020, to July 2020) providing mean, standard deviation, and Sharpe ratios for Naïve and optimized Sharpe ratio of portfolios

\begin{tabular}{lllll}
\hline $\begin{array}{l}\text { Metal } \\
\text { commodities } \\
\text { futures }\end{array}$ & $\begin{array}{l}\text { Metal commodity } \\
\text { futures only }\end{array}$ & $\begin{array}{l}\text { Metal + energy } \\
\text { futures }\end{array}$ & $\begin{array}{l}\text { Metal commodity } \\
\text { futures only }\end{array}$ & $\begin{array}{l}\text { Metal + } \\
\text { energy } \\
\text { futures }\end{array}$ \\
& Naïve portfolio (1/5) & $\begin{array}{l}\text { Naïve portfolio } \\
(1 / 10)\end{array}$ & $\begin{array}{l}\text { Optimized Sharpe } \\
\text { ratio }\end{array}$ & $\begin{array}{l}\text { Optimized } \\
\text { Sharpe ratio }\end{array}$ \\
Mean & $82.03 \%$ & $8.34 \%$ & $86.61 \%$ & $86.61 \%$ \\
Standard deviation & $22.60 \%$ & $42.88 \%$ & $16.85 \%$ & $16.85 \%$ \\
Sharpe ratio & 3.606 & 0.182 & 5.11 & 5.11 \\
\hline
\end{tabular}

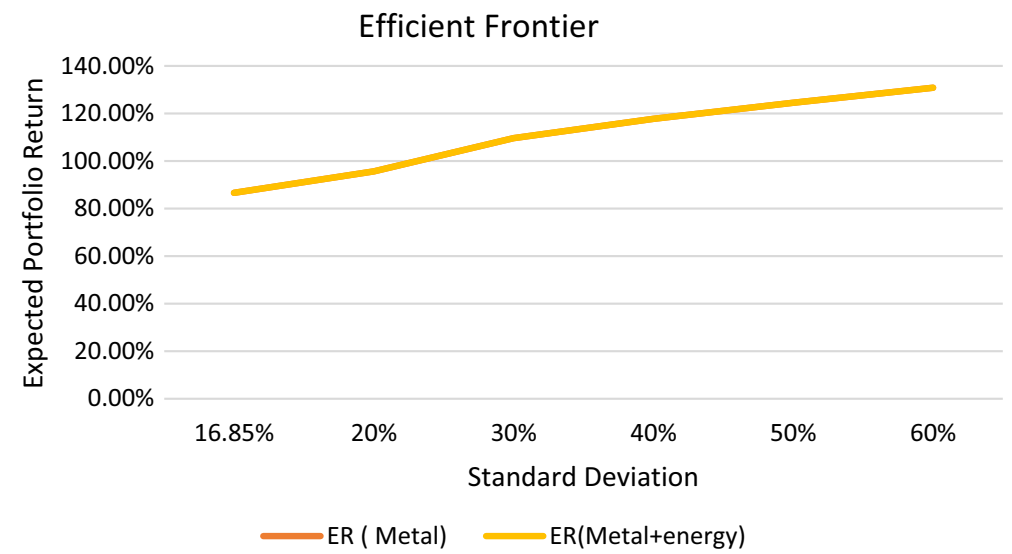

Fig. 14 Efficient frontier of a portfolio of metal commodity futures along with an energy commodity futures' diversified portfolio March 11, 2020, to July 2020 (Covid 19) 


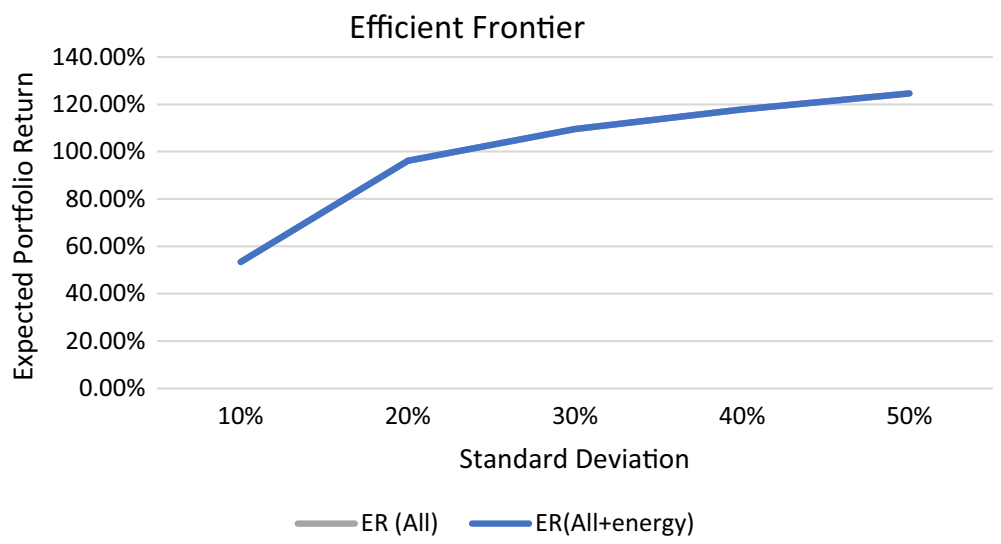

Fig. 15 Efficient frontier of a portfolio of all commodity futures along with an energy commodity futures' diversified portfolio March 11, 2020, to July 2020 (Covid 19)

Table 18 Descriptive statistics for All commodity futures with and without energy commodity futures for portfolio diversification during Covid 19 from March 11, 2020, to July 2020, providing mean, standard deviation, and Sharpe ratios for Naïve and optimized Sharpe ratio of portfolios

\begin{tabular}{lllll}
\hline $\begin{array}{l}\text { All commodities } \\
\text { futures }\end{array}$ & $\begin{array}{l}\text { All commodity } \\
\text { futures only }\end{array}$ & $\begin{array}{l}\text { All + energy } \\
\text { commodity } \\
\text { futures } \\
\text { Nä̈ve portfolio } \\
(1 / 14)\end{array}$ & $\begin{array}{l}\text { All commodity } \\
(1 / 19)\end{array}$ & $\begin{array}{l}\text { All + energy } \\
\text { fommodity } \\
\text { futures }\end{array}$ \\
\hline $\begin{array}{l}\text { Mean } \\
\text { Standard deviation }\end{array}$ & $\begin{array}{l}28.24 \% \\
16.15 \%\end{array}$ & $3.61 \%$ & $\begin{array}{l}\text { Optimized Sharpe } \\
\text { ratio }\end{array}$ & $\begin{array}{l}\text { Optimized } \\
\text { Sharpe ratio }\end{array}$ \\
Sharpe ratio & 1.715 & $25.92 \%$ & $67.22 \%$ & $67.14 \%$ \\
\hline
\end{tabular}

\subsection{Commodity futures diversification for constraints on weights}

In addition to checking for diversification of commodity futures using long positions, we also analyze for diversification results by applying additional constraints on the weights of the assets in portfolios. The previous results had long positions in the assets, where we also observed that allowing for short positions in the commodities' futures improves our results. Table 10 provides results on portfolio diversification for all commodity classes that we discussed in the study, with and without energy commodities, when the weights of individual assets in a portfolio cannot be less than $5 \%$ and cannot be greater than $50 \%$. That is, we solve the following for optimized Sharpe ratio:

Maximize $\frac{w^{T} \mu-r_{f}}{\sqrt{w^{T} \Sigma w}}$,

Subject to

$\sum_{i=1}^{m} w_{i}=1$, 


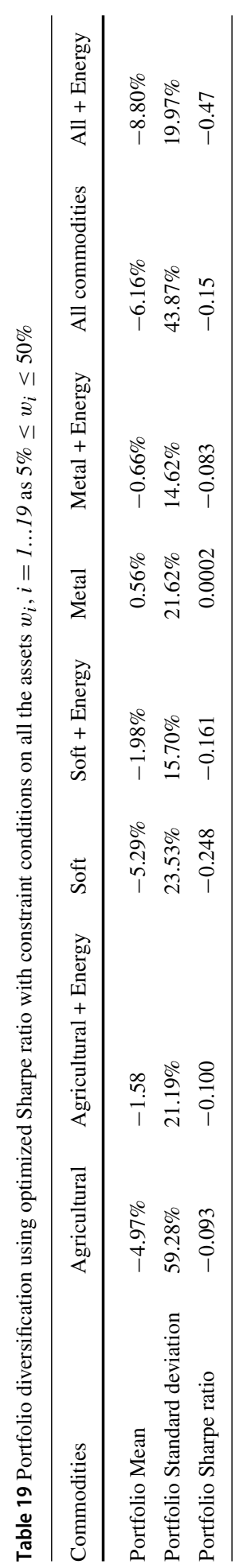




$$
5 \% \leq w_{i} \leq 50 \% \text { for all } i=1, \ldots, m
$$

It is observed that, in the case of agricultural commodities, the addition of the energy commodity futures improves results for both the standard deviation or risk and portfolio return. The portfolio return is improved by $68 \%$, whereas the volatility is decreased by $28.5 \%$ when the energy commodity futures have been added to the existing portfolio. Similar results have been observed for soft commodities' portfolios. The addition of energy commodity futures has increased the returns by $62.5 \%$ and has decreased the risk by $33.3 \%$. The optimized Sharpe ratio is improved though still negative due to negative returns. In the case of a portfolio for metal commodities, it's been seen that the return for an energy commodities' diversified portfolio has decreased and a decrease in the risk. However, the reduction in risk is not enough for the Sharpe ratio to improve due to negative returns. Similar results have been seen in the case of an all commodities futures portfolio. The addition of energy commodity futures has decreased the risk by $54.5 \%$, but the return has also reduced by a good $43 \%$. Therefore, depending on the class of commodities used in the portfolio, diversification results may differ. It is observed that the risk is reduced significantly in all the diversified portfolios.

\subsection{Minimax strategy for portfolio optimization}

Martin Young introduced a new principal, minimax, of portfolio optimization based on historical data in 1998 (Young, 1998). The work became the basis for linear programming methods where optimization is a simple linear program solution. The optimal portfolio is the one that would minimize the maximum losses over past historical data. The solution is constrained on the minimum acceptable level of an average return across all observed periods. We adopt Young's model to check for robustness in our model.

There are 19 commodities futures in our analysis that span over 10 years from January 2011 to July 2020. We let $R_{t, i}$ be the annual return on the security $i$. As before in Eq. $2, \mu_{i, t} i=$ $1 \ldots 19$ over time $t=1 \ldots 10$, be the average annual return on the security $i$ from January 2011 to July 2020. Let $R_{t}=\sum_{i=1}^{19} w_{i} R_{i, t}$ be the portfolio return for year $t$ and $R=\sum_{i=1}^{19} w_{i} \mu_{i, t}$ be the average portfolio return. We use the equivalent formulation for minimax portfolio optimization (Young, 1998) and maximize expected portfolio return subject to a restriction that the portfolio return is greater than or equal to some threshold level $X$ in each period. That is, we solve the following system:

$$
\begin{aligned}
& \operatorname{Max} \sum_{i=1}^{19} w_{i} \mu_{i, t} \\
& \text { Subject to } \sum_{i=1}^{19} w_{i} R_{i, t} \geq X, \text { for } t=1, \ldots, 10 \\
& \sum w_{i}=1, \quad w_{i} \geq 0 \text { for each } i
\end{aligned}
$$

We solve the system in Eq. 10 with $X=-0.25$ for each period. The results for each portfolio with and without the inclusion of energy commodities futures are provided in Table 20. The system is solved in Excel using the solver package to find the optimal weights. The weights are then used to calculate the portfolio mean, standard deviation, and Sharpe ratio. We provide results for the four classes discussed in the study.

Table 20 shows that the energy derivatives have significantly improved the Sharpe ratio of the resulting diversified portfolios in all the cases. The increase is around $135 \%$ for agricultural 


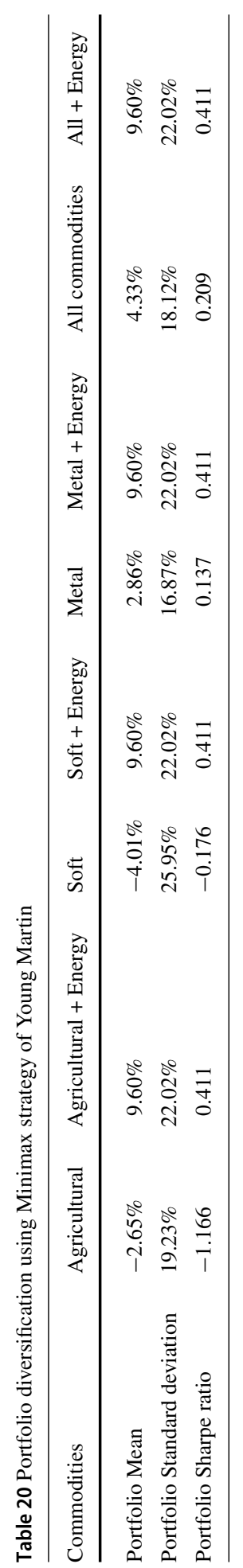


commodities futures portfolio, $333 \%$ for soft commodities futures portfolio, $200 \%$ for metal commodities futures portfolio, and $97 \%$ for all commodities futures. The results are consistent with optimized Sharpe ratio results in that the energy commodities futures improve the existing commodities futures portfolios in all classes. The returns of the diversified portfolios have significantly increased while the standard deviations have reduced in almost all cases.

\section{Discussion}

The current study provides an empirical analysis of the characteristics of energy futures in diversifying the existing commodities futures' portfolios. The study considers four different portfolios for the analysis using multiple metrics for portfolio diversification. The portfolios analyzed consist of agricultural commodities, soft commodities, and metal commodities futures. We also examine the results for diversification for a portfolio of all the (non-energy) commodities used in the study. Naïve portfolios, Markowitz mean-variance portfolios, optimized Sharpe ratios, and minimax strategy are used as metrics to study the diversification results using energy futures on the commodity portfolios. As analyzed in the previous section, our results are quite conclusive. In all the cases above, it was observed that the portfolios with energy futures provide better returns and reduced standard deviation when compared to the respective non-diversified portfolios of commodities. The energy future diversified portfolios outperformed all the other portfolios in Markowitz mean-variance analysis and optimized Sharpe ratios analysis. However, the diversified naïve portfolios did not perform well in any case, even though in the agriculture and energy portfolio, the naïve portfolio did show a reduction in the risk level. The results are improved due to a reduction in the risk and an increase in the return on the portfolios.

We also checked our results for an added set of constraints in subsection 4.4 by restricting the weights of each asset to be between 5 and 50\%. The results show that in all the commodities' futures classes, the inclusion of the energy commodities futures has lowered the portfolio's risk. However, the Sharpe ratio improves for agricultural and soft commodities portfolios by increasing the return on the portfolio and the inclusion of energy commodities futures in the diversified portfolios. The other two cases show a decrease in the Sharpe ratio due to a worsened expected return. Further to that, we also applied the minimax strategy of Young's to check for the robustness in our model in Sect. 4.5. The results show that the diversified portfolios with the inclusion of energy commodities futures provide better results in all the four commodities' portfolios in our analysis. The improved Sharpe ratios are obtained by an increase in the expected return on the diversified portfolios and a decrease in the risk as measured by standard deviation.

The results for pre-crisis and covid 19 are also worth noting. Subsection 4.2 on the precrisis period of the study shows that the inclusion of the energy derivatives futures increases the Sharpe ratio when optimizing Sharpe ratio is used as a metric for portfolio optimization in all the cases. The results show that the diversified portfolio with energy commodities futures increases the portfolio returns and decreases the risk of the portfolio. The results for naïve portfolios show that in almost all cases, the inclusion of energy derivatives reduces the portfolio risk though decreases the Sharpe ratio. The results for the covid 19 periods in the study, March 11, 2020, to July 2020, show that the energy commodities futures significantly improve the results for the Sharpe ratio in the agricultural and soft commodities futures portfolios by increasing the Sharpe ratio. However, for the metal and all commodities futures, the results are the same with and without the inclusion of energy commodities futures. The 
results on the naïve portfolios show a decreased Sharpe ratio for the energy commodities futures diversified portfolios. This is because the energy commodities futures have been volatile during the covid 19 periods. However, given that the study dataset only comprises a few months of covid, anything conclusive requires further exploration.

There has not been enough research on the diversification properties of energy futures on the other financial commodities. Ours is the first study that analyzes the effects of energy futures on commodity futures. There has been some work where crude oil, natural gas, or coal futures have been studied for diversification amongst other individual commodities or bonds and stocks portfolios. For instance, we could only find one paper by Rehman et al. that observed the diversification of crude oil, natural gas, and coal on some other commodities. They concluded that crude oil provides better diversification results for gold and silver; gas futures give better results when combined with copper, wheat, platinum, palladium, and coal, providing better diversification results for gold, silver, and wheat (Rehman et al., 2019). They conducted the study on the weekly data from January 2010 to December 2018.

Our study investigates the diversification of four existing commodity futures portfolios for agricultural, soft commodities, metal, and all commodities (considered in the survey) futures with a portfolio of energy futures and not by individual energy futures on a daily dataset from January 2011 to July 2020. Furthermore, we apply the modern portfolio theory concepts and optimize both mean by giving an acceptable risk level and optimizing the Sharpe ratio. The current study covers a more extended period and more commodities from different segments of the market. The study finds that the energy futures significantly improve the returns, reduce risk, and improve Sharpe ratios in agricultural commodities, metals, soft commodities portfolios, and a portfolio containing all the commodities.

Most studies have discussed portfolio diversification using crude oil or crude oil derivatives on stock and bond portfolios or indices in the literature. For instance, Geman and Kharoubi studied the maturity effect in the diversification of the S\&P 500 index using WTI crude oil futures and concluded in favor of diversification using crude oil futures (Geman \& Kharoubi, 2008). (Galvani \& Plourde, 2010) figured that energy futures fail to increase the return in the diversified portfolio equities but tend to reduce the risk while conducting a study on the data from 1990-2008. We also analyze the diversification of commodity futures using only crude oil futures on the same dataset from January 2011 to July 2020. The analysis is done by optimizing the Sharpe ratio for the portfolios with and without crude oil futures to study the effects of diversification on the portfolios. Our results in Table 21 show that crude oil futures fail to diversify the existing commodity futures portfolios for all the portfolios considered in our analysis. These results could be because of the crude oil futures' overall poor performance during the chosen period. The high volatility of around $132 \%$ and a negative return of approximately $52 \%$ per annum make crude oil the least favorite future of the selected setting for diversification purposes.

We add to the literature by studying diversification using energy futures on the portfolios mean-variance and Sharpe ratio optimized portfolios of commodities instead of commodity indices or stock and bond indices with energy futures. We observe that the level of diversification varies amongst the commodity classes' choices and at the level of risk when optimizing mean for a given level of risk under Markowitz mean-variance analysis. We found that the diversified portfolio has increased the return by $500 \%$ at a risk level of around $20 \%$ for agricultural commodities. We also observed that efficient frontier results are worsened after a certain level of risk in the Markowitz mean-variance analysis when diversified using energy futures for soft commodities portfolio. Therefore, we think that portfolio managers need to look at an individual class of commodities to cater to the needs of their portfolio while trying to diversify their portfolios using energy futures instead of indices. 
Table 21 Portfolio diversification with optimized Sharpe ratio using crude oil futures only

\begin{tabular}{lll}
\hline Portfolios & Without energy futures & $\begin{array}{l}\text { With crude oil } \\
\text { futures }\end{array}$ \\
\hline $\begin{array}{l}\text { Agricultural } \\
\text { commodities }\end{array}$ & Mean: $-6.18 \%$ & Mean: $-6.18 \%$ \\
& SD: $110.63 \%$ & SD: $110.63 \%$ \\
& SR: -0.061 & SR: -0.061 \\
Soft commodities & Mean: $-3.13 \%$ & Mean: $-3.13 \%$ \\
& SD: $32.95 \%$ & SD: $32.95 \%$ \\
Metal commodities & SR: -0.112 & SR: -0.112 \\
& Mean: $5.71 \%$ & Mean: $5.71 \%$ \\
& SD: $19.93 \%$ & SD: $19.93 \%$ \\
All commodities except & SR: 0.259 & SR: 0.259 \\
energy & Mean: $5.71 \%$ & Mean: $5.71 \%$ \\
& SD: $19.93 \%$ & SD: $19.93 \%$ \\
& SR: 0.259 & SR: 0.259
\end{tabular}

Our contributions to the existing literature are pretty significant. We have performed an empirical analysis on a current set of data that spans from January 2011 to July 2020 by comparing mean-variance efficient frontiers of different commodity futures portfolios with the addition of energy futures. Our results show that the diversification properties of energy futures are both in terms of reducing risk and increasing the return of the portfolios. In addition to that, we compare the naïve portfolios and conclude that the naïve portfolios decrease the overall return of the diversified portfolios and increase the risk in the portfolios. The results are pretty conclusive for the three periods explored in the study: the entire duration of the study, pre-crisis, and covid 19 periods. We also provide the diversification results using an optimized Sharpe ratio and observe that the Sharpe ratio increases in all the portfolios when energy futures are added to commodity futures portfolios. The result may not be true for metal and all commodities futures in the covid 19 period due to a small set of data. We further observed that if we allow short sales in the futures contracts, the results improve for the metal futures portfolio and all commodity portfolios by taking the optimized Sharpe ratio to 1.23 , increasing more than $175 \%$. Lastly, we studied the results by restricting our constraints further and applying the minimax strategy of Young in our work and the other metrics. The results are robust under the two methodologies. Therefore, we conclude that the energy commodities futures improve the Sharpe ratios and return while decreasing the risk of the portfolios in all the studied cases and hence be explored by investors for possible portfolio diversification.

\section{Conclusion}

Globalization and recent economic developments have brought the energy futures to the front lines as an investment and diversification opportunity for investors, fund, and portfolio managers. The low transactional, storage and insurance costs compelled the fund managers to explore new avenues for portfolio diversification especially using energy derivatives. In the 
current study, we provide empirical evidence that energy futures increase the potential gain as well as reduce the risk of the portfolios when added to existing commodity portfolios. Using Markowitz's mean-variance framework, we showed that a higher level of expected returns is achieved for the energy futures diversified portfolio for the same level of risk in almost all studied portfolios. We further found that naïve portfolios fail to diversify the existing portfolios and therefore do not recommend naïve portfolio strategies for diversification.

The optimized Sharpe ratio analysis shows that energy futures have an excellent potential for diversification of commodity futures portfolios in all the analyzed cases in the study. More than a $400 \%$ increase in the portfolio return has been observed in soft commodity portfolios when energy futures have been added to diversify. Furthermore, the diversified portfolio reduced the risk of the agriculture commodity portfolio by around $80 \%$ when the Sharpe ratio is used as an optimization measure for the portfolio. In addition to that, we find that the inclusion of multiple energy futures in the existing portfolios provides better portfolio diversification with an increase in the Sharpe ratios and increased returns for the same level of risk. Therefore, we conclude that energy futures offer excellent opportunities to diversify commodity portfolios, and investors should explore diversification using energy futures. We validated these results under different optimization techniques (minimax, added constraints), periods (pre-crisis, covid 19, and overall), and metrics (naïve, mean-variance, Sharpe ratio) and established that the energy commodities futures have beneficial portfolio diversification characteristics. Furthermore, our results show that crude oil futures fail to optimize the commodity futures portfolios for the chosen period. Additionally, we also found that the results have the potential to be improved when the short positions in the futures comprising the portfolio are allowed in some cases.

From a policy point of view, the study also reveals that several energy futures have a comparative advantage in diversifying with just one energy futures. It is also observed that crude oil is not the best suitable diversification futures contract in the energy futures. Therefore, we recommend that the investors, fund, and portfolio managers explore multiple energy futures while diversifying their existing portfolios, look for sophisticated diversification metrics strategies, and go beyond diversification and hedging using just oil futures. For the future, an exciting dimension of work could be on energy commodities futures and their hedging strategies using minimum cVaR (Chai \& Zhou, 2018). The effects of maturity of futures contracts, optimal rebalancing, and international diversification in commodity futures are some areas of interest that future researchers may like to explore. Therefore, we recommend that energy futures be explored during such situations, not only as diversification of portfolios but also as a derivatives class.

Funding Social Science Planning Programs of Shandong Province (21DJJJ16: Research on the spatial and temporal network structure and influence mechanism of foreign trade in Shandong Province under the background of international trade friction. General Projects of Key R \& D Programs in Shandong Province (Soft Science Projects) (2020RKB01267): Influence of Technological Innovation on Green Growth of Manufacturing Industry in Shandong Province under the Constraint of Environmental Regulation.

\section{References}

Arreola Hernandez, J. (2014). Are oil and gas stocks from the Australian market riskier than coal and uranium stocks? Dependence risk analysis and portfolio optimization. Energy Economics, 45, 528-536. https:// doi.org/10.1016/j.eneco.2014.08.015 
Barsky, R. B., \& Kilian, L. (2004). Oil and the macroeconomy since the 1970s. Journal of Economic Perspectives, 18(4), 115-134. https://doi.org/10.1257/0895330042632708

Bessler, W., \& Wolff, D. (2015). Do commodities add value in multi-asset portfolios? An out-of-sample analysis for different investment strategies. Journal of Banking and Finance, 60, 1-20. https://doi.org/10.1016/j. jbankfin.2015.06.021

Bodie, Z. (1983). Commodity futures as a hedge against inflation. The Journal of Portfolio Management, 9(3), 12-17. https://doi.org/10.3905/jpm.9.3.12

Bodie, Z., \& Rosansky, V. I. (1980). Risk and Return in Commodity Futures. Financial Analysts Journal, 36(3), 27-39. https://doi.org/10.2469/faj.v36.n3.27

Cesarone, F., Scozzari, A., \& Tardella, F. (2013). A new method for mean-variance portfolio optimization with cardinality constraints. Annals of Operations Research, 205(1), 213-234. https://doi.org/10.1007/ s10479-012-1165-7

Chai, S., \& Zhou, P. (2018). The Minimum-CVaR strategy with semi-parametric estimation in carbon market hedging problems. Energy Economics, 76, 64-75. https://doi.org/10.1016/j.eneco.2018.09.024

Chang, C. L., McAleer, M., \& Tansuchat, R. (2011). Crude oil hedging strategies using dynamic multivariate GARCH. Energy Economics, 33(5), 912-923. https://doi.org/10.1016/j.eneco.2011.01.009

Cheung, C. S., Miu, P., Cheung, C. S., \& Miu, P. (2010). Diversification benefits of commodity futures. Journal of International Financial Markets, Institutions and Money, 20(5), 451-474.

Chong, J., \& Miffre, J. (2010). Conditional correlation and Volatility in Commodity Futures and Traditional Asset Markets. Journal of Alternative Investments.

Elsayed, A. H., Nasreen, S., \& Tiwari, A. K. (2020). Time-varying co-movements between energy market and global financial markets: Implication for portfolio diversification and hedging strategies. Energy Economics, 90, 104847. https://doi.org/10.1016/j.eneco.2020.104847

Fabozzi, F. J., Huang, D., \& Zhou, G. (2010). Robust portfolios: Contributions from operations research and finance. Annals of Operations Research, 176(1), 191-220. https://doi.org/10.1007/s10479-009-0515-6

Galvani, V., \& Plourde, A. (2010). Portfolio diversification in energy markets. Energy Economics, 32(2), 257-268. https://doi.org/10.1016/j.eneco.2009.05.015

Gatfaoui, H. (2016). Linking the gas and oil markets with the stock market: Investigating the U.S. relationship. Energy Economics, 53, 5-16. https://doi.org/10.1016/j.eneco.2015.05.021

Gatfaoui, H. (2019). Diversifying portfolios of U.S. stocks with crude oil and natural gas: A regime-dependent optimization with several risk measures. Energy Economics, 80, 132-152. https://doi.org/10.1016/j. eneco.2018.12.013

Geman, H., \& Kharoubi, C. (2008). WTI crude oil Futures in portfolio diversification: The timeto-maturity effect. Journal of Banking and Finance, 32(12), 2553-2559. https://doi.org/10.1016/j. jbankfin.2008.04.002

Gorton, G., \& Geert Rouwenhorst, K. (2006). Facts and fantasies about commodity futures. Financial Analysts Journal, 62(2), 47-68. https://doi.org/10.2469/faj.v62.n2.4083

Guerard, J. B., Markowitz, H., Xu, G., \& Wang, Z. (2018). Global portfolio construction with emphasis on conflicting corporate strategies to maximize stockholder wealth. Annals of Operations Research, 267(1-2), 203-219. https://doi.org/10.1007/s10479-016-2380-4

Huynh, T. L. D., Shahbaz, M., Nasir, M. A., \& Ullah, S. (2020). Financial modelling, risk management of energy instruments and the role of cryptocurrencies. Annals of Operations Research. https://doi.org/10.1007/ s10479-020-03680-y

Jensen, G. R., Johnson, R. R., \& Mercer, J. M. (2000). Efficient use of commodity futures in diversified portfolios. Journal of Futures Markets, 20(5), 489-506. https://doi.org/10.1002/(SICI)1096-9934(200005 20:5\%3c489::AID-FUT5\%3e3.0.CO;2-A

Johnson, L. L. (1960). The theory of hedging and speculation in commodity futures. Review of Economic Studies. https://doi.org/10.2307/2296076

Kang, S. H., McIver, R., \& Yoon, S. M. (2017). Dynamic spillover effects among crude oil, precious metal, and agricultural commodity futures markets. Energy Economics, 62, 19-32. https://doi.org/10.1016/j. eneco.2016.12.011

Khalfaoui, R., Sarwar, S., \& Tiwari, A. K. (2019). Analysing volatility spillover between the oil market and the stock market in oil-importing and oil-exporting countries: Implications on portfolio management. Resources Policy, 62, 22-32. https://doi.org/10.1016/j.resourpol.2019.03.004

King, A. J. (1993). Asymmetric risk measures and tracking models for portfolio optimization under uncertainty. Annals of Operations Research, 45(1), 165-177. https://doi.org/10.1007/BF02282047

Levy, H. (1987). Futures, spots, stocks and bonds: Multi-asset portfolio analysis. Journal of Futures Markets, 7(4), 383-395. https://doi.org/10.1002/fut.3990070404 
Liagkouras, K., Metaxiotis, K., \& Tsihrintzis, G. (2020). Incorporating environmental and social considerations into the portfolio optimization process. Annals of Operations Research. https://doi.org/10.1007/ s10479-020-03554-3

Liu, Q., \& Tu, A. H. (2012). Jump spillovers in energy futures markets: Implications for diversification benefits. Energy Economics, 34(5), 1447-1464. https://doi.org/10.1016/j.eneco.2012.06.015

Markowitz, H. (1952). Portfolio Selection. The Journal of Finance (Vol. 7).

Ogryczak, W. (2000). Multiple criteria linear programming model for portfolio selection. Annals of Operations Research, 97(1-4), 143-162. https://doi.org/10.1023/A:1018980308807

Rehman, M. U., Bouri, E., Eraslan, V., \& Kumar, S. (2019). Energy and non-energy commodities: An asymmetric approach towards portfolio diversification in the commodity market. Resources Policy, 63, 101456. https://doi.org/10.1016/j.resourpol.2019.101456

Sadorsky, P. (2014). Modeling volatility and correlations between emerging market stock prices and the prices of copper, oil and wheat. Energy Economics, 43, 72-81. https://doi.org/10.1016/j.eneco.2014.02.014

Sarwar, S., Khalfaoui, R., Waheed, R., \& Dastgerdi, H. G. (2019a). Volatility spillovers and hedging: Evidence from Asian oil-importing countries. Resources Policy, 61, 479-488. https://doi.org/10.1016/j. resourpol.2018.04.010

Sarwar, S., Shahbaz, M., Anwar, A., \& Tiwari, A. K. (2019b). The importance of oil assets for portfolio optimization: The analysis of firm level stocks. Energy Economics, 78, 217-234. https://doi.org/10.1016/ j.eneco.2018.11.021

Sarwar, S., Tiwari, A. K., \& Tingqiu, C. (2020). Analyzing volatility spillovers between oil market and Asian stock markets. Resources Policy, 66, 101608. https://doi.org/10.1016/j.resourpol.2020.101608

Sarwar, S., Waheed, R., Amir, M., Khalid, M., Sarwar, S., Waheed, R., et al. (2018). Role of Energy on Economy The Case of Micro to Macro Level Analysis. Economics Bulletin, 38(4), 1905-1926.

Sharpe, W. F. (1966). Mutual Fund Performance. The Journal of Business, 39(S1), 119. https://doi. org/10.1086/294846

Su, C.-W., Qin, M., Tao, R., \& Umar, M. (2020). Financial implications of fourth industrial revolution: Can bitcoin improve prospects of energy investment? Technological Forecasting and Social Change, 158, 120178. https://doi.org/10.1016/j.techfore.2020.120178

Su, C.-W., Sun, T., Ahmad, S., \& Mirza, N. (2021). Does institutional quality and remittances inflow crowd-in private investment to avoid Dutch Disease? A case for emerging seven (E7) economies. Resources Policy, 72, 102111. https://doi.org/10.1016/j.resourpol.2021.102111

Tao, R., Su, C.-W., Xiao, Y., Dai, K., \& Khalid, F. (2020). Robo advisors, algorithmic trading and investment management: Wonders of fourth industrial revolution in financial markets. Technological Forecasting and Social Change. https://doi.org/10.1016/j.techfore.2020.120421

Umar, M., Mirza, N., Rizvi, S. K. A., \& Furqan, M. (2021a). Asymmetric volatility structure of equity returns: Evidence from an emerging market. The Quarterly Review of Economics and Finance. https:// doi.org/10.1016/j.qref.2021.04.016

Umar, M., Rizvi, S. K. A., \& Naqvi, B. (2021b). Dance with the devil? The nexus of fourth industrial revolution, technological financial products and volatility spillovers in global financial system. Technological Forecasting and Social Change, 163, 120450. https://doi.org/10.1016/j.techfore.2020.120450

Umar, M., Su, C.-W., Rizvi, S. K. A., \& Lobonţ, O.-R. (2021c). Driven by fundamentals or exploded by emotions: Detecting bubbles in oil prices. Energy, 231, 120873. https://doi.org/10.1016/j.energy.2021.120873

Wen, X., \& Nguyen, D. K. (2017). Can investors of Chinese energy stocks benefit from diversification into commodity futures? Economic Modelling, 66, 184-200. https://doi.org/10.1016/j.econmod.2017.06.016

You, L., \& Daigler, R. T. (2013). A Markowitz Optimization of Commodity Futures Portfolios. Journal of Futures Markets, 33(4), 343-368. https://doi.org/10.1002/fut.21553

Young, M. R. (1998). A Minimax Portfolio Selection Rule with Linear Programming Solution. Management Science, 44(5), 673-683.

Publisher's Note Springer Nature remains neutral with regard to jurisdictional claims in published maps and institutional affiliations. 